\title{
Do larger boards improve shareholder value creation? - Effects of the board size on business performance in Eastern Central Europe
}

\author{
ZSOLT LAKATOS
}

Doctoral School of General and Quantitative Economics, Department of Finance, Corvinus University of Budapest, Hungary

Received: May 9, 2019 • Revised manuscript received: January 27, 2020 • Accepted: February 16, 2020

Published online: May 4, 2020

(C) 2020 The Author(s)

\begin{abstract}
The aim of this study is to analyse the impact of board size on a firms' operational and market performance at the largest East Central European listed non-financial, non-public utility firms. The literature debates the effects of the size of the board. While the resource dependency theory supports a positive effect, the agency theory supports a negative impact on firm value. This question is rarely investigated in two-tiered corporate governance models. This paper estimates the effects of management board and supervisory board size, between 2007 and 2016. The results indicate that the effect of management board size depends heavily on the size of the observed company. In both fixed effects and GMM-type dynamic panel regression models, using Tobin's Q, market-to-book ratio, total shareholder value and ROA as firm performance measures, increase in management board size has a significant positive impact on firm performance; however, in the case of larger firms, the effect is significantly negative. Moreover, the increase in the ratio of outside directors has a positive impact on the firm's performance in all dynamic panel regression models and this effect is even more significant in Tobin's Q and market-to-book ratio models. This can indicate the effective monitoring role of the supervisory board.
\end{abstract}

\section{KEYWORDS}

corporate governance, board size, firm performance

\section{JEL-CODES}

G30, G31, G32, G34

E-mail: zsolt.lakatos@uni-corvinus.hu 


\section{INTRODUCTION}

Corporate governance has become a popular research field in management sciences in the last 30 years, although a single definition for corporate governance does not exist. According to Dobák and Steger (2003: 223), 'corporate governance from an overall perspective is the structuring of the control mechanisms, monitoring, and organisation of a company or a group of companies in a manner that satisfies owners' objectives.' A well-known definition of corporate governance comes from Shleifer and Vishny (1997), who consider it as how investors get the managers to give them their money back.

The significance of corporate governance structure is the separation of ownership and control in public companies was first described by Berle and Means (1932). According to them, professional managers run the company because they have expertise, but the shareholders as the owners of the company, bear the risks. Therefore, a corporate unit must exist that can protect the interests of the owners. This unit is called the Board of Directors. Modern corporate governance theory is based on the seminal study of Jensen and Meckling (1976) that forms the foundation of the agency theory.

In practice, two fundamental corporate governance models can be distinguished, the onetiered and the two-tiered models. The Anglo-Saxon or Anglo American (Anglo-US) corporate governance structure is known as one-tiered, while the German-Japanese model is called twotiered. In the one-tiered structure, the Board of Directors represents the interests of the owners and this unit consists of the managers of the company (insiders) and individuals who are independent of the company (outsiders). In the two-tiered structure, there are two boards. The first is called the Board of Directors or management board, and the other, the supervisory board. The first board consist of insiders, while the supervisory board consists of outsiders.

The crucial question is, how the interests of the owners can be protected. This process is called monitoring. According to Agrawal and Knoeber (2012), monitoring can be realised by large shareholders, the Board of Directors and the market of corporate control. This latter represents the shareholders' rights regarding takeover of the firm. The main roles of the Board of Directors are the monitoring of the management, rewarding or penalizing the managers and advising on the strategic decision-making process. Agrawal and Knoeber (2012) mention that the Board of Directors is typically measured by two characteristics, its size (number of members) and its composition (proportion of members who are outsiders or independent of the management).

In corporate governance studies, the main question usually relates to identifying the connection between corporate governance characteristics and a firms' financial performance. As Michelberger (2016: 85) writes, 'well governed firms should have a higher firm performance and value.' He also (2016: 86) mentions that 'several studies [...] indicate that companies with good corporate governance have better long-term performance for shareholders or in terms of general business performance.'

Researchers have been looking for the answers to whether there is an optimal size of corporate boards, and how corporate governance should improve to contribute better financial performance. Lipton and Lorsch (1992) recommended measures for improving corporate governance, arguing that the source of failures is not incomplete legal regulations, but oversised boards. Large boards can lead to weaker control mechanisms. Lipton and Lorsch thought that corporate boards are responsible for the ineffective companies' performance, and argued that the 
only way to improve firm performance is by improving the efficiency of the Board of Directors. Board size was seen as crucial in this perspective.

Jensen (1993) disagreed with Lipton and Lorsch, and recommended that boards should not exceed eight people, and that board members should have high equity. Nguyen et al. (2015) references both Lipton and Lorsch (1992) and Jensen (1993), in finding that the relation between board size and firm value is not uniformly decreasing. 'When boards are relatively small, adding more directors can increase the firm's value because the latter bring their expertise and relationships that increases the firm's competitiveness' (Nguyen et al. 2015: 5).

Jensen (1993) listed four control forces which can influence managers' behaviour to improve firm performance and act in shareholders' interests: capital markets or market for corporate control; the legal, political and regulatory system; product and factor markets; and an effective internal control system.

Although corporate governance has been studied for more than 30 years, how to improve it is still a crucial field of research. On October 18, 2018, over twenty prominent executives, representing some of America's largest corporations, pension funds and investment firms, came together to sign the Commonsense Principles 2.0. They included Warren Buffet, Jamie Dimon (Chairman and CEO of JPMorgan Chase) and Larry Fink (Chairman and CEO of BlackRock). One of the key principles states that 'while no one size fits all - boards need to be large enough to allow for a variety of perspectives, as well as to manage required board processes - they generally should be as small as practicable so as to promote an open dialogue among directors' (Commonsense Principles 2.0 2018: 2).

The current study aims to clarify whether the size of corporate boards affects the business and market performance of the biggest East Central European listed companies. The database used consists of the largest 300 listed companies in the region, with financial data for the period 20072016. This region is characterised by two-tiered corporate governance systems, in which there is a management board consisting of executive company directors, and a supervisory board comprising independent members. The management board is responsible for operational activities and making strategic decisions, and the supervisory board for monitoring the management board.

The relevance of this paper emerges from the lack of similar research about the relation between corporate board size and firm performance in East Central European region, with such a large panel database, considering both the relatively large number of companies and time interval. The corporate governance literature has shown a huge interest in this research topic over the past 30 years, and consequently, many papers have been published, both on developed and developing countries.

This paper is structured as follows. After reviewing the relevant literature in Section 2, the paper will introduce the database, the methodology set up and the hypothesis in Section 3. In Section 4, the author will discuss the results. The paper ends with the conclusions in Section 5.

\section{LITERATURE REVIEW}

Various corporate governance theories consider the relation between the board and the management differently. Agency theory emphasises the conflict of interest between the board and the management (Jensen - Meckling 1976). The board represents the interests of the shareholders, and so its most important task is monitoring the management. The role of the board is 
maximising shareholders' wealth, reducing agency costs, selecting and rewarding the Chief Executive Officer (CEO), evaluating CEO and company performance, making strategic decisions and achieving management control (Zahra - Pearce 1989). On the other hand, according to the resource dependency theory, there is no such conflict of interest between the board and the management; the main role of the board is to provide the resources for the firm (Zahra - Pearce 1989). Resource dependency theory considers corporate boards to be a cooperative mechanism to extract resources vital to company performance, and that boards are to serve a boundary spanning role, enhancing organisational legitimacy (Zahra - Pearce 1989).

According to Lipton and Lorsch (1992) and Jensen (1993), who represent agency theory, large boards are not advantageous, because they are associated with weaker monitoring and slow decision-making. Other representatives of resource dependence theory like Dalton et al. (1999), find large boards favourable, and they emphasise the importance of the board's advice to the management. Agrawal and Knoeber (2012: 8) find a trade-off between more information and more effective decision-making:

Bigger boards bring more (sources of) information but make coming to a collective decision more difficult. Similarly, more outsider-oriented boards sacrifice information that insiders bring but may be more unified in what to do given the available information. An optimal board is one with the size and composition that adjusts this trade-off to maximise firm value. If boards are constituted optimally, they likely will differ across firms, reflecting the relative value of better information and better execution.

Empirical studies usually found a negative relationship between board size and firm performance. Among US firms, Yermack (1996) found that board size has a significant negative impact on firm performance, regardless of whether firm performance is proxied with Tobin's Q or ROA. He confirmed this negative impact in OLS and fixed effects econometric models. With American data, this significant negative impact has been confirmed by other authors as well, including Vafeas (1999) with Tobin's Q in OLS models, Cheng et al. (2008) with Tobin's Q and ROA in OLS models and Coles et al. (2008) with Tobin's Q also in OLS models.

In developed economies, most of the studies confirmed the negative relationship between board size and firm performance, regardless of whether firm performance is measured with Tobin's Q or ROA. Some of the authors are Bozec (2005) with Canadian firm data, Conyon and Peck (1998) with Danish, Dutch, French and Italian data, Bennendsen (2008) with Danish data, Eisenberg et al. (1998) with Finnish data, Postma et al. (2001) with Dutch data, Loderer and Peyer (2002) and Beiner et al. (2004) with Swiss data, Mak and Kusnadi (2005) and Haniffa and Hudaib (2006) with Malaysian data, and Mak and Kusnadi (2005) with firm from Singapore. Only Beiner et al. (2006) found a significant positive impact for board size on firm performance using Tobin's Q in OLS model. While Haniffa and Hudaib (2006) reported a significant positive relationship between board size and ROA, Loderer and Peyer (2002) only confirmed the positive relationship using ROA as firm performance.

Guest (2009) also confirmed the negative relationship between board size and firm performance with British data using ROA, Tobin's Q and share return. Guest used interaction terms between board size and firm characteristics such as firm size or leverage, to separate the sample into small and large companies. The negative coefficient of the interaction term between board size and firm size indicates that increasing board size does not contribute to improving firm performance at large corporations. Nguyen et al. (2015), using Australian data, also confirmed 
the negative impact of board size on firm performance, for Tobin's Q in OLS and fixed effects models, and ROA in OLS models.

In the East and Central European region, Gugler et al. (2014) did a similar study. They found a significant positive relation between board size and Tobin's Q in the sample of eleven Central and Eastern European countries in the OLS models. Moscu (2013) found an insignificant positive relation between board size and ROA in the OLS models among Romanian listed companies. Ionascu et al. (2018) analysed the relationship between women on boards and financial performance among Romanian companies and found that board size has an insignificant negative impact on ROA in the OLS models, but an insignificant positive effect in the fixed effects models. Dobija and Kravchenko (2017) found an insignificant negative relation between board size and ROA in the OLS models.

In the East Central European region, joint stock companies usually operate in a two-tiered corporate governance structure. For listed companies, the two-tier structure is obligatory in the Czech and Slovak Republics, and in Poland. In Bulgaria, Hungary and Romania, a one-tiered structure is allowed. In this region, if a two-tiered structure is applied, a management board and a supervisory board exist separately. In these six countries, the management board is called differently (see Table 1). The management board is primary responsible for business management, while the supervisory board monitors the management board in the interests of shareholders. The management board consists of directors of the company; in Hungary and Poland, directors can have an employment agreement with the company, which is not allowed in

Table 1. Corporate governance characteristics in East Central Europe

\begin{tabular}{|c|c|c|c|c|c|}
\hline & Bulgaria & $\begin{array}{l}\text { Czech Republic } \\
\text { and Slovakia }\end{array}$ & Poland & Hungary & Romania \\
\hline $\begin{array}{l}\text { What is called that } \\
\text { manages the firm }\end{array}$ & $\begin{array}{l}\text { Board of Directors or } \\
\text { Management Board }\end{array}$ & $\begin{array}{l}\text { Board of } \\
\text { Directors }\end{array}$ & $\begin{array}{l}\text { Management } \\
\text { Board }\end{array}$ & $\begin{array}{c}\text { Board of Directors } \\
\text { or Management } \\
\text { Board }\end{array}$ & $\begin{array}{l}\text { Board of Directors or } \\
\text { Management Board }\end{array}$ \\
\hline Supenisory board & \multicolumn{5}{|c|}{ mandatory in two-tier structure } \\
\hline $\begin{array}{l}\text { Main task of supervisory } \\
\text { board }\end{array}$ & \multicolumn{5}{|c|}{ monitoring the company management or management board } \\
\hline $\begin{array}{l}\text { Main tasks of } \\
\text { management board } \\
\text { and the Board of } \\
\text { Directors }\end{array}$ & \multicolumn{5}{|c|}{ managing the company, operative management, constitute firm strategy } \\
\hline Supervisory board size & minimum 3 & $\begin{array}{c}\text { minimum } 3 \\
\text { Czechia: } \\
\text { multiples of } 3\end{array}$ & minimum 3 & $\begin{array}{c}\text { minimum } 3 \\
\text { maximum } 15\end{array}$ & $\begin{array}{c}\text { minimum } 3 \text { maximum } \\
7\end{array}$ \\
\hline Management board size & minimum 1 & minimum 1 & minimum 1 & $\begin{array}{l}\operatorname{minimum} 3, \\
\text { maximum } 11\end{array}$ & minimum 1 \\
\hline $\begin{array}{l}\text { Supenvisory board } \\
\text { independency }\end{array}$ & $\begin{array}{c}\text { Members are } \\
\text { independent individuals } \\
\text { and firm employees but } \\
\text { one third should be } \\
\text { independent }\end{array}$ & $\begin{array}{l}\text { Members are } \\
\text { independent } \\
\text { individuals }\end{array}$ & $\begin{array}{c}\text { Members are } \\
\text { independent } \\
\text { individuals }\end{array}$ & $\begin{array}{l}\text { Members are } \\
\text { independent } \\
\text { individuals }\end{array}$ & $\begin{array}{c}\text { Members are } \\
\text { independent } \\
\text { individuals and firm } \\
\text { employees }\end{array}$ \\
\hline
\end{tabular}

Source: compiled by the author. 
Bulgaria, Romania and in the Czech and Slovak Republics. Table 1 shows further characteristics of corporate governance in East Central Europe.

\section{DATA AND METHODOLOGY}

\subsection{Sample and descriptive statistics}

The database includes data from 300 Bulgarian, Czech, Hungarian, Romanian, Polish and Slovakian listed companies, excluding the strongly regulated financial and utility sectors. Financial data have been downloaded from the Bloomberg monitor system, while information on corporate boards have been collected manually from annual reports. Financial data are year-end data (December 31), while the size of the board (number of directors) reflects the status as of January 1 in the given year. The dataset covers the years between 2007 and 2016. Theoretically, there should be 3,000 firm-year observations available for each variable, but as Table 2 shows, a number of observations are missing, especially in earlier years. This means that the sample is an unbalanced panel dataset. Missing data can impact the significance levels of the variables. The main cause of the missing observations is unavailable data or the fact that the firm was not operational in a given year.

Descriptive statistics of the sample are presented in Table 3. The average management board size is 3.83 and the median is 3 , while the average supervisory board size is 5.57 and the median is 5. Comparing these values with other studies, these board sizes are considered small on average. In the sample, the standard deviation of the management board size is 1.886 and that of the supervisory board size is 1.703 . These variabilities can make regression results powerful. The outside director ratio denotes the supervisory board size divided by the sum of supervisory board size and management board size. This measure matches the ratio of outside or non-executive directors on the Board of Directors in the one-tiered corporate governance system.

The pairwise correlation among all the variables used in regression models are reported in Table 4. Market performance measures such as Tobin's $Q$ and total shareholder return correlate

Table 2. Number of observations of board sizes and firm performance measures in each year

\begin{tabular}{|l|c|c|c|c|c|}
\hline Year & Management Board size & Supervisory Board size & Tobin's Q and P/BV & TSR & ROA \\
\hline 2016 & 300 & 300 & 291 & 300 & 291 \\
\hline 2015 & 300 & 300 & 295 & 300 & 297 \\
\hline 2014 & 300 & 300 & 295 & 300 & 297 \\
\hline 2013 & 297 & 297 & 285 & 291 & 294 \\
\hline 2012 & 287 & 287 & 276 & 279 & 291 \\
\hline 2011 & 281 & 281 & 268 & 255 & 288 \\
\hline 2010 & 255 & 255 & 238 & 240 & 276 \\
\hline 2009 & 233 & 233 & 223 & 231 & 259 \\
\hline 2008 & 214 & 212 & 207 & 207 & 235 \\
\hline 2007 & 203 & 200 & 183 & 182 & 217 \\
\hline
\end{tabular}

Source: compiled by the author. 
negatively with management board size, but positively with outside director ratio. Operational performance measures like ROA correlate in the opposite direction. Firm size correlates moderately positively with management board size, but negatively with outside director ratio, while firm size correlates negatively with all performance measures. CAPEX and cash variables correlate positively with performance measures, but leverage correlates negatively and so do net fixed assets and leverage variables.

Table 5 presents the statistical summary of the sample of my study. Of the 300 companies, more than $70 \%$ are Polish. The average size of the management board is the largest in Hungary with 6 members and the lowest in Poland, with 3.13 members. There is no big difference with respect to supervisory board size among the observed countries. Hungarian firms employ the most employees and their revenues are the highest on average, while the average of firms' market capitalization is the highest in the Czech Republic. The average Tobin's Q is the biggest among Polish companies and the average total shareholder return the largest among Bulgarian firms, while the average ROA is the biggest among Czech companies. Most companies are from the industrial sector, but the largest companies are from the energy sector, all of them oil and gas companies.

Table 3. Descriptive statistics

\begin{tabular}{|l|c|c|c|c|c|c|c|c|}
\hline Variables & Obs & Mean & St. Dev. & \multicolumn{1}{|c|}{ Min } & Max & 25th percentile & Median & 75th percentile \\
\hline Management Board size & 2,668 & 3.834 & 1.886 & 1.000 & 13.000 & 3.000 & 3.000 & 5.000 \\
\hline Log Mgmt Board size & 2,668 & 1.226 & 0.496 & 0.000 & 2.565 & 1.099 & 1.099 & 1.609 \\
\hline Supervisory Board size & 2,663 & 5.573 & 1.703 & 1.000 & 15.000 & 5.000 & 5.000 & 6.000 \\
\hline Outside director ratio & 2,660 & 0.603 & 0.113 & 0.250 & 0.889 & 5.000 & 0.625 & 7.000 \\
\hline Firm size & 2,754 & 4.463 & 1.666 & -4.871 & 9.702 & 3.389 & 4.351 & 5.397 \\
\hline Tobin's Q & 2,561 & 1.456 & 1.514 & 0.210 & 43.133 & 0.879 & 1.097 & 1.503 \\
\hline MB ratio & 2,561 & 1.839 & 2.210 & 0.142 & 14.883 & 0.7108 & 1.178 & 1.982 \\
\hline TSR & 2,585 & 0.194 & 1.524 & -0.999 & 66.923 & -0.213 & 0.045 & 0.369 \\
\hline ROA & 2,748 & 0.041 & 0.138 & -2.073 & 2.822 & 0.012 & 0.041 & 0.080 \\
\hline Age & 2,561 & 9.233 & 5.464 & 1.000 & 23.000 & 4.000 & 9.000 & 14.000 \\
\hline Volatility & 2,585 & 0.285 & 7.330 & 0.000 & 341.181 & 0.021 & 0.027 & 0.035 \\
\hline One-tiered management & 2,665 & 0.143 & 0.350 & 0.000 & 1.000 & 0.000 & 0.000 & 0.000 \\
\hline Minority & 2,754 & 0.027 & 0.085 & -0.790 & 1.401 & 0.000 & 0.000 & 0.020 \\
\hline Cash & 2,754 & 0.085 & 0.103 & 0.000 & 0.992 & 0.019 & 0.048 & 0.113 \\
\hline Leverage & 2,708 & 0.139 & 0.129 & 0.000 & 1.401 & 0.046 & 0.108 & 0.195 \\
\hline CAPEX & 2,635 & 0.062 & 0.068 & 0.000 & 0.829 & 0.020 & 0.042 & 0.080 \\
\hline Net Fixed Assets & 2,745 & 0.364 & 0.227 & 0.000 & 0.971 & 0.171 & 0.360 & 0.525 \\
\hline
\end{tabular}

Source: author.

Notes: Management Board size denotes the number of directors on the management board. Log Mgmt Board size denotes the natural logarithm of Management Board size. Supervisory Board size denotes the number of directors on the supervisory board. Outside director ratio denotes the ratio between supervisory board size and the sum of management and supervisory board size. Firm size denotes the natural logarithm of total assets. Tobin- $Q$ is proxied by the market value of equity plus total liabilities plus preferred equities, scaled by total assets. TSR denotes total shareholder return that equals the annual percentage change of share price plus dividend yield. ROA is Net Income scaled by Total Assets. 
Table 4. Correlation between the main variables

\begin{tabular}{|c|c|c|c|c|c|c|c|c|}
\hline & 1 & 2 & 3 & 4 & 5 & 6 & 7 & 8 \\
\hline 1. Tobin's $Q$ & 1.0000 & & & & & & & \\
\hline 2. MB ratio & $0.8479 *$ & 1.0000 & & & & & & \\
\hline 3. TSR & $0.2580^{*}$ & $0.2125^{*}$ & 1.0000 & & & & & \\
\hline 4. ROA & $0.2409 *$ & $0.1563 *$ & 0.1991* & 1.0000 & & & & \\
\hline 5. Log Boardsize & $-0.0623^{*}$ & -0.0228 & -0.0364 & 0.0063 & 1.0000 & & & \\
\hline 6. Log Boardsize*Firmsize & $-0.1736^{*}$ & $-0.1175^{*}$ & $-0.0583^{*}$ & -0.0015 & $0.8263^{*}$ & 1.0000 & & \\
\hline 7. Ouside director ratio & $0.0493^{*}$ & 0.0233 & 0.0227 & -0.0134 & $-0.7993^{*}$ & $-0.5775^{*}$ & 1.0000 & \\
\hline 8. Log Boardsize*Outside director & $-0.0409 *$ & -0.0008 & $-0.0397^{*}$ & -0.0011 & $0.8870^{*}$ & $0.7552 *$ & $-0.4909 *$ & 1.0000 \\
\hline 9. Firmsize & $-0.2833^{*}$ & $-0.2283^{*}$ & $-0.0594 *$ & $-0.0413^{*}$ & $0.4128 *$ & $0.8171^{*}$ & $-0.1968 *$ & $0.4227^{*}$ \\
\hline 10. Net Fixed Assets & $-0.0781^{*}$ & $-0.0772 *$ & -0.0202 & -0.0133 & $0.2317^{*}$ & $0.5232 *$ & $-0.0419 *$ & $0.2830 *$ \\
\hline 11. Leverage & $-0.1158 *$ & -0.0138 & -0.0227 & $-0.1443^{*}$ & 0.0047 & $0.1056 *$ & 0.0189 & 0.0153 \\
\hline 12. CAPEX & $0.1059 *$ & $0.0970 *$ & -0.028 & $0.0807^{*}$ & 0.0115 & -0.0061 & 0.0252 & $0.0463^{*}$ \\
\hline 13. One tiered management & $-0.0833^{*}$ & $-0.0821 *$ & 0.0226 & -0.0335 & $0.3080^{*}$ & $0.0928 *$ & $-0.3721^{*}$ & $0.1859 *$ \\
\hline 14. Minority & $-0.1025^{*}$ & $-0.1117^{*}$ & 0.0005 & -0.0336 & $0.0538 *$ & $0.1275^{*}$ & $-0.0787^{*}$ & -0.0032 \\
\hline 15. Age & $-0.1727^{*}$ & $-0.1164^{*}$ & 0.0018 & -0.0227 & $0.1764^{*}$ & $0.2381 *$ & $-0.1339 *$ & $0.1290^{*}$ \\
\hline 16. Volatility & -0.0104 & -0.0126 & 0.0202 & -0.0025 & $-0.0443^{*}$ & -0.0262 & 0.0365 & $-0.0454^{*}$ \\
\hline 17. Cash lag1 & $0.3355^{*}$ & $0.2567^{*}$ & $0.0458 *$ & $0.2098^{*}$ & 0.008 & $-0.0775^{*}$ & -0.0203 & -0.0051 \\
\hline 18. Log Boardsize*Leverage & $-0.1064 *$ & -0.0119 & -0.0339 & $-0.1215^{*}$ & $0.4103^{*}$ & $0.4409 *$ & $-0.3118^{*}$ & $0.3711^{*}$ \\
\hline 19. Log Boardsize*Cash lag1 & $0.2678^{*}$ & $0.2128^{*}$ & 0.0255 & $0.1900 *$ & $0.3144^{*}$ & $0.1821 *$ & $-0.2742 *$ & $0.2563 *$ \\
\hline
\end{tabular}

Source: author.

Notes: Pearson product moment correlations between main financial and corporate governance variables *denotes significance at $5 \%$ significance level. MB ratio denotes market value of equity divided by book value of equity. Age is the number of years since the firm was first listed on the stock exchange. Volatility is the annual volatility of the daily effective yield of share price. One-tier management is a dummy variable which's value is one if a firm uses a one-tier corporate governance system in each year. Minority denotes minority non-controlling interests divided by total shareholder equity. Cash denotes cash and cash near items scaled by total assets. Leverage denotes total debts divided by total assets. CAPEX denotes capital expenditures scaled by total assets. Net Fixed Assets denotes gross fixed assets minus accumulated depreciation scaled by total assets.

\subsection{Model specification}

In the regression models, the dependent variables are the three most popular firm market performance measures, and one firm operational performance measure used by other authors: Tobin's Q, market-to-book value ratio (MB ratio), total shareholder return (TSR) and ROA. Tobin's $\mathrm{Q}$ is used as a proxy for firm value and is calculated according to Chung and Pruitt (1994); the MB ratio and TSR reflect the judgement of the market, while ROA expresses the firm's operational effectiveness. Tobin's $Q$ denotes the ratio of market value of equity plus total debts plus minority interests plus preferred equities, scaled by total assets. The MB ratio denotes the ratio of the market value of equity and book value of equity. TSR is the sum of the annual yield of the share prices plus the dividend yield. Dividend yield is the ratio of the dividend paid divided by the market value of equity in the previous year. ROA denotes the net income scaled by total assets. 


\begin{tabular}{|c|c|c|c|c|c|c|c|c|c|c|}
\hline $\mathbf{9}$ & $\mathbf{1 0}$ & $\mathbf{1 1}$ & $\mathbf{1 2}$ & $\mathbf{1 3}$ & $\mathbf{1 4}$ & $\mathbf{1 5}$ & $\mathbf{1 6}$ & $\mathbf{1 7}$ & $\mathbf{1 8}$ & 19 \\
\hline & & & & & & & & & & \\
\hline & & & & & & & & & & \\
\hline & & & & & & & & & & \\
\hline & & & & & & & & & & \\
\hline & & & & & & & & & & \\
\hline & & & & & & & & & & \\
\hline & & & & & & & & & & \\
\hline & & & & & & & & & & \\
\hline 1.0000 & & & & & & & & & & \\
\hline $0.5370^{*}$ & 1.0000 & & & & & & & & & \\
\hline $0.1844^{*}$ & $0.1350^{*}$ & 1.0000 & & & & & & & & \\
\hline $0.0776^{*}$ & $0.0895^{*}$ & $0.1603^{*}$ & 1.0000 & & & & & & & \\
\hline $0.0896^{*}$ & $-0.0648^{*}$ & $-0.0591^{*}$ & 0.0164 & 1.0000 & & & & & & \\
\hline $0.1636^{*}$ & $0.0849^{*}$ & 0.0167 & $-0.0681^{*}$ & $-0.0497^{*}$ & 1.0000 & & & & & \\
\hline $0.2450^{*}$ & $0.0836^{*}$ & $-0.0480^{*}$ & $-0.1401^{*}$ & $0.0929^{*}$ & $0.0854^{*}$ & 1.0000 & & & & \\
\hline 0.0089 & -0.0069 & 0.0179 & -0.0045 & -0.0142 & 0.029 & $0.0440^{*}$ & 1.0000 & & & \\
\hline $0.1724^{*}$ & $-0.0623^{*}$ & $-0.1881^{*}$ & $0.0427^{*}$ & $-0.0422^{*}$ & -0.0168 & $-0.0641^{*}$ & -0.0161 & 1.0000 & & \\
\hline $0.3326^{*}$ & $0.2625^{*}$ & $0.8460^{*}$ & $0.1303^{*}$ & $0.0539^{*}$ & 0.0385 & 0.011 & -0.0089 & $-0.1562^{*}$ & 1.0000 & \\
\hline 0.0122 & -0.0092 & $-0.1714^{*}$ & 0.021 & 0.0298 & 0.0106 & 0.028 & -0.0233 & $0.8828^{*}$ & $-0.0455^{*}$ & 1.0000 \\
\hline
\end{tabular}

Although some authors have warned against the using Tobin's Q as a firm performance measure (Bartlett - Partnoy 2018; Dybvig - Warachka 2010), Tobin's Q is by far the most popular market performance measure. The second most popular is the MB ratio and the third is annual stock return, while the most popular accounting-based measurement is ROA, followed by ROE (Al-Matari et al. 2014). Table 6 shows the pair-wise correlations between the performance measures. Since ROA is considered the best operational measure (Hagel et al. 2013) and the correlation between Tobin's $\mathrm{Q}$ and ROA is the highest, in this sense, Tobin's $\mathrm{Q}$ is still considered the best market performance measure.

The paper adopts the techniques used by Yermack (1996) and Guest (2009). Yermack took the natural logarithm of the board size and justified assuming a convex association between board size and firm market value. In the regression models, the two main independent variables are the natural logarithm of management board size and outside director ratio. The first plays a role similar to the board of directors ${ }^{1}$ and the other to the outside director ratio in one-tiered corporate governance studies. In the one-tiered corporate governance structure, the Board of Directors consists of the executive directors who run the company and non-executive directors

${ }^{1}$ The board of directors consists of executive and non-executive or independent directors. Their proportion is called the outside director ratio and it links to the board's capability of monitoring firm management effectively. 
Table 5. Summary statistics

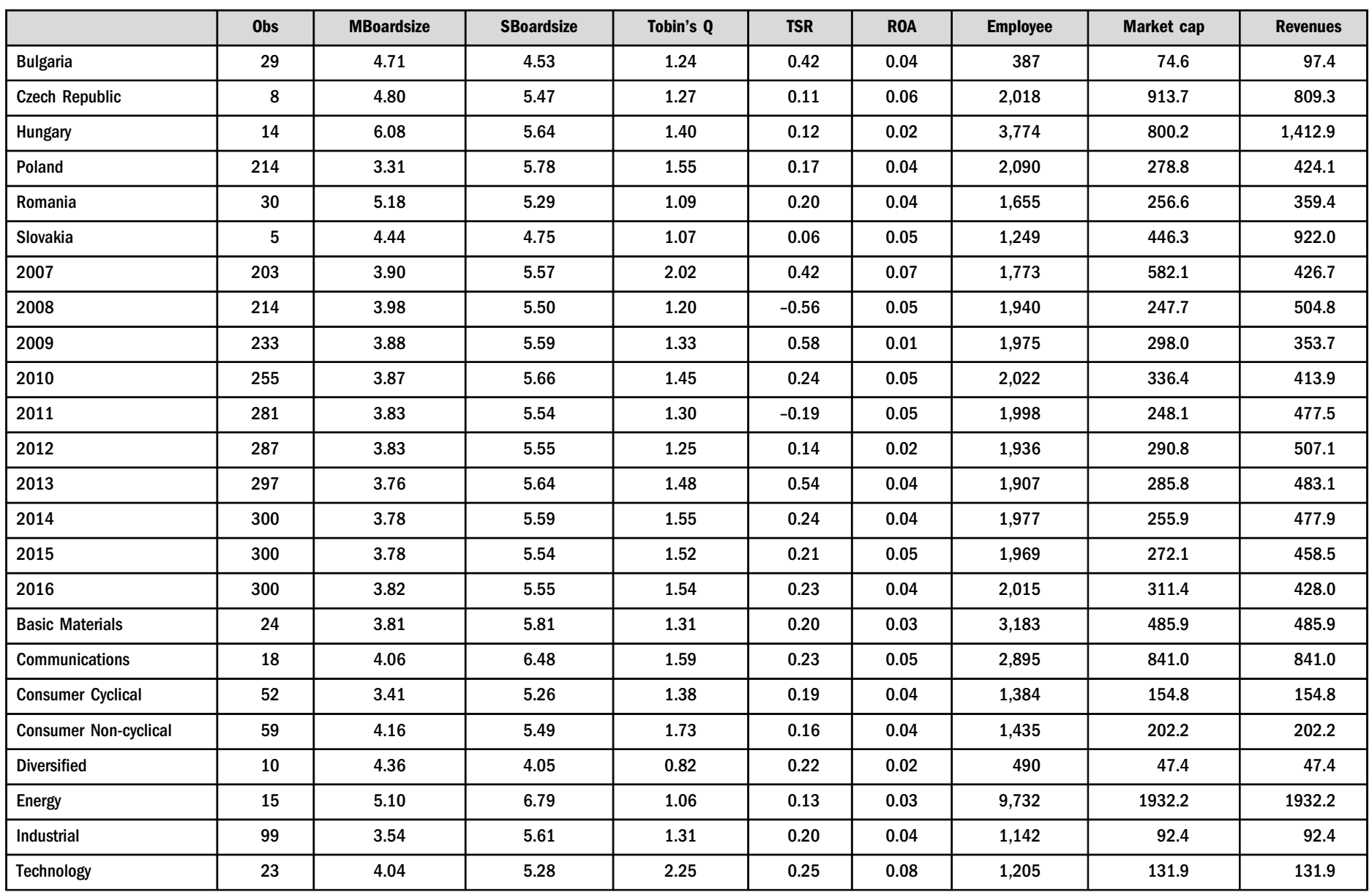

Source: author.

Notes: Obs denotes the number of observations. Observations per year refer to the number of board size members. The other values are averages. 
Table 6. Correlation matrix of the dependent variables

\begin{tabular}{|l|l|l|l|l|l|}
\hline & TSR & Tobin's Q & MB ratio & ROA & ROE \\
\hline TSR & 1.0000 & & & & \\
\hline Tobin's Q & $0.2580^{*}$ & 1.0000 & & & \\
\hline MB ratio & $0.2125^{*}$ & $0.8479^{*}$ & 1.0000 & & \\
\hline ROA & $0.1991^{*}$ & $0.2409^{*}$ & $0.1563^{*}$ & 1.0000 & \\
\hline ROE & $0.1223^{*}$ & $0.2165^{*}$ & $0.1787^{*}$ & $0.7278^{*}$ & 1.0000 \\
\hline
\end{tabular}

Source: author.

Note: *denotes significance at the $5 \%$ level.

who are independent of the company. In this sense, it a reasonable assumption that the size of the Board of Directors can have an impact on firm performance. In the two-tiered structure, the management board (sometimes called the Board of Directors) consists of the executive directors. Outside director ratio denotes the size of supervisory board divided by the sum of the size of management and supervisory boards. Size refers to the number of directors.

As in all similar studies, control variables are used to isolate the effect of board size on firm value. With these variables, the effects of potential firm characteristics effects can be controlled. Leverage denotes long-term liabilities divided by total assets. According to empirical facts, larger firms are older and have higher debts than younger and smaller firms. Nguyen et al. (2015) mentioned the tax saving advantage of higher debts, while according to Jensen (1993), higher debt can impose stricter discipline on management. A further control variable is net fixed assets scaled by total assets. Nguyen et al. (2015: 7) claim that 'higher fixed asset ratio implies higher operating leverage. By using higher operating leverage firms may be able to leverage their underlying profitability and thus increase their market value.'

Controlling for growth opportunities, a variable called CAPEX is used, which denotes capital expenditure scaled by total assets. Nguyen et al. (2015: 7) argue that 'higher levels of capital expenditures or investments should produce higher cash flow in future years.' A further control variable being used is called one-tiered management, which equals one if corporate governance structure is one-tiered at a firm in a given year. Another control variable is minority, which denotes minority non-controlling interests divided by total shareholder equity. The last control variable is cash, which denotes cash plus cash-near items scaled by total assets.

Besides these control variables, four interaction terms are used, similarly to Guest (2009). Using interaction terms is based on Coles et al. (2008), who argue that the impact of board size on performance will differ for different types of firms. The first interaction variable is management board size multiplied by firm size. The second interaction variable is management board size multiplied by the outside director ratio. The first and second interaction terms both indicate large firms and the second term shows the effectiveness of the supervisory board. The third interaction variable is management board size multiplied by leverage. This variable also indicates large companies, and allows controlling for the leverage effect. Nguyen et al. (2015) mentioned that highly levered firms require greater expertise to access external resources. On the other hand, according to Guest (2009), for large, old and highly leveraged firms, a large board size may be an optimal value maximising outcome. The last interaction term is management board size multiplied by the first lag of the variable cash, which allows for controlling for the effect of large cash. 
The main econometric model is the following:

$$
\begin{aligned}
\text { Firm }_{\text {performance it }}= & \text { const }+\beta_{1} \text { LogMBoardsize }_{i t}+\beta_{2} \cdot \text { Outside director ratio }_{i t} \\
& +\beta_{\mathrm{i}} \cdot \text { Control variables }_{\mathrm{it}}+\gamma_{\mathrm{i}} \cdot \text { Interaction variables }_{\mathrm{it}}+\alpha_{\mathrm{i}}+\delta_{\mathrm{t}}+\varepsilon_{\mathrm{it}}
\end{aligned}
$$

$\alpha_{\mathrm{i}}$ : individual, firm or unobserved effects, time-invariant heterogeneity

$\delta_{\mathrm{t}}$ : time dummies

$\varepsilon_{\text {it: }}$ idiosyncratic error terms

In corporate governance studies, the most popular regression technique is the pooled OLS model; but in this actual study, only two kinds of regression models are used: fixed effetcs panelregressions with year dummies, and GMM-type dynamic panel-regression. The pooling of data (pooled OLS) means that in this regression model, each firm observation is treated as a separate observation without considering that it may come from the same firm. One important OLS model assumption cannot be met because the error terms are correlated across time. Using a fixed effects panel-regression model, it is possible to control for the unobserved firm-specific characteristics, because this regression modelling technique allows unobserved variables to be correlated with the error term. So, the endogeneity problem, which is related to omitted variables, can be partially solved. F-test indicates whether the results of the firm fixed effects models are correct and the joint significance of the fixed effects intercepts. The null hypothesis is that all the fixed effects are zero. If the null hypothesis is rejected, then the fixed effects technique needs to be used to get correct results.

Besides the fixed effects model, the GMM dynamic panel regression technique can help to solve the endogeneity problem. As Guest (2009: 15) mentions: 'a major econometric concern highlighted by recent studies is that past and current firm performance determines board size. [...] fixed effects analysis will be biased in the presence of such dynamic and simultaneous endogeneity.' Guest employed a GMM-type dynamic panel-regression technique. As Guest (2009: 17) explains, 'this approach allows board size (and other explanatory variables) to be determined by past and present performance but not future performance, and therefore provides an appropriate econometric specification for dealing with the endogeneity problems faced here.'

Stata version 13 has been used to run econometric models.

\subsection{Hypotheses}

To set up hypothesis, the mean and median values of Tobin's Q, TSR and ROA have been plotted against the size of the management board and supervisory board. This is represented in Figs 1-3. Since the calculation of Tobin's Q and MB ratio are very similar, only Tobin's Q has been illustrated. The figures present the same picture, as can be seen from the pairwise correlation values. There is a negative relation between management board size and market performance measures and a positive relation between management board size and operational performance measures.

Based on the figures, the following hypotheses can be formulated:

- H1: There is a negative relationship between management board size and firm market performance measures.

- H2: There is a positive relationship between management board size and firm operational performance measures. 


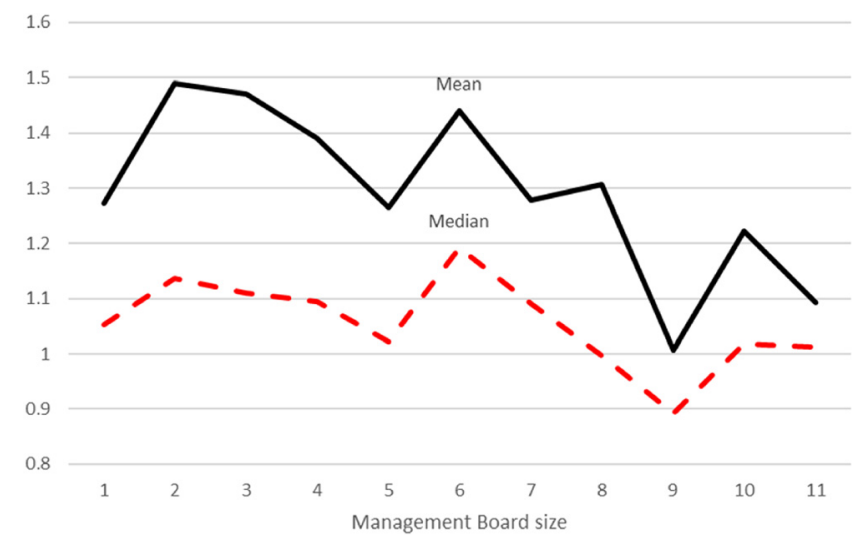

Fig. 1. Mean and median values of Tobin-Q according to the size of management board

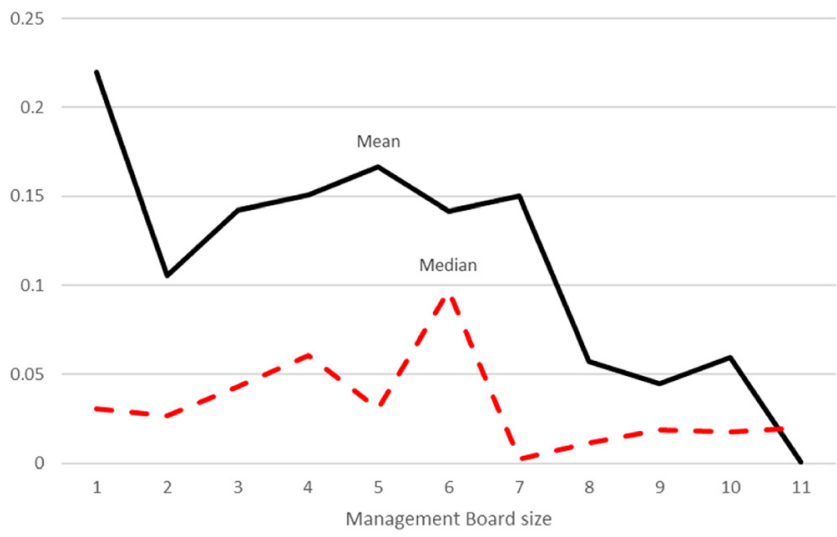

Fig. 2. Mean and median values of TSR according to the size of management board

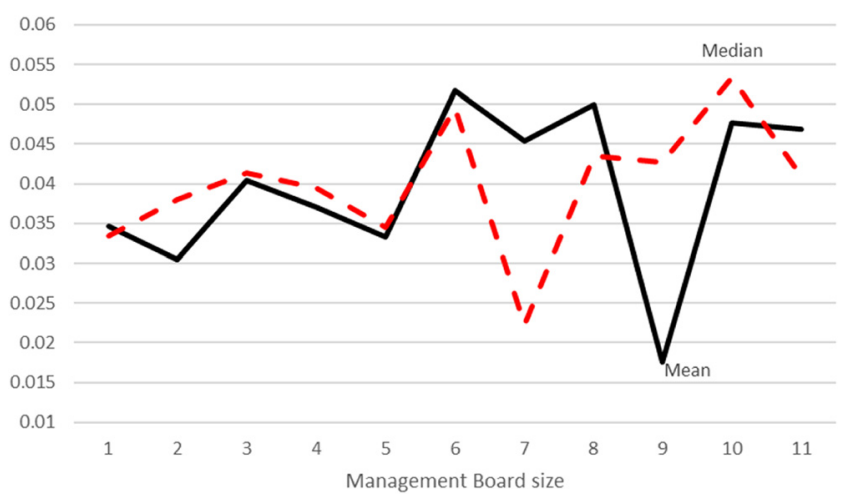

Fig. 3. Mean and median values of ROA according to the size of management board 
Based on pairwise correlation, the following hypotheses can be expected:

- H3: There is a positive relationship between the outside director ratio and firm market performance measures.

- H4: There is a negative relationship between the outside director ratio and firm operational performance measures.

- H5: Using board size multiplied by the firm size interaction term, board size has a positive impact on firm performance, but this interaction term has a negative impact on firm performance.

\section{EMPIRICAL RESULTS}

\subsection{Fixed effects regression}

Detailed regression results can be found in the Appendix of the paper. Table 7 shows the most frequent signs of the significant variables in fixed effects regression models by firm performance measures. Non-significant signs are in brackets. This means that if Tobin's Q is used as a firm performance measure, the variable Log Boardsize has a significant positive impact on firm performance in most of the models, except in Model 2, where this effect is negative and not significant. According to Table 7, there are only three variables which have the same impact on firm performance in each of the firm performance measures: Log Boardsize, Log Boardsize*Firmsize and Log Boardsize*Cash lag1.

In fixed effects models, using Tobin's Q, Market-to-book ratio, total shareholder return or ROA as firm performance measure, management board size has a significant positive impact on firm performance, while the interaction term between board size and firm size has a significant negative impact on firm performance. This confirms Hypothesis H5 and the results of Guest (2009). In the two-tiered corporate governance structure, the management board usually consists of directors who are managing the company. They are experts in different fields, including the CEO, the Chief Financial Officer, the Chief Operating Officer, the Chief Technology Officer, or the Chief Human Resources Officer. So, it can be reasonably assumed that if more experts run a firm, the firm can benefit from this.

These are consistent with the results of other researchers such as Jensen (1993; cited by Nguyen et al. 2015: 5), who claimed that 'when boards are relatively small, adding more directors can increase a firm's value because the latter bring their expertise and relationships that increase a firm's competitiveness.' The significant negative sign of the interaction term indicates that for large firms, increasing board size has a negative impact on firm performance. This result is the same as Guest's. Operations of larger firms are more complex, involving more directors, but it is not effective to increase the size of the management board.

The positive significant effect of the interaction term between board size and the first lag of cash indicates the positive effect of bank monitoring and the disciplining impact of large excess cash. In the case of TSR and ROA, this effect is also positive, but not significant.

According to the fixed effects regressions, the outside director ratio has a negative impact on firm market performance and a positive impact on operative performance. This result does not support the corporate governance assumption that an increase in the share of independent members in corporate boards has a positive impact on firm performance. In the two-tiered corporate governance structure, the supervisory board monitors the management board. 
Table 7. Signs of independent variables

\begin{tabular}{|c|c|c|c|c|}
\hline & Tobin's Q & MB & TSR & ROA \\
\hline Log Boardsize & + & + & $(+)$ & $(+)$ \\
\hline Log Boardsize*Firmsize & - & - & - & - \\
\hline Outside director ratio & - & - & $(-)$ & $(+)$ \\
\hline Log Boardsize*Outside director & $(-)$ & $(-)$ & $(+)$ & $(-)$ \\
\hline Firmsize & - & - & - & $(+)$ \\
\hline Net Fixed Assets & $(-)$ & $(-)$ & - & - \\
\hline Leverage & - & + & + & - \\
\hline CAPEX & + & + & $(+)$ & + \\
\hline One-tiered_management & $(+)$ & $(+)$ & $(+)$ & - \\
\hline Minority & $(-)$ & $(+)$ & $(+)$ & + \\
\hline Age & - & - & $(-)$ & - \\
\hline Volatility & $(+)$ & $(+)$ & $(+)$ & $(-)$ \\
\hline LogBoardsize*Leverage & $(-)$ & $(-)$ & $(-)$ & $(+)$ \\
\hline Log Boardsize*Cash lag1 & + & + & $(+)$ & $(+)$ \\
\hline Cash lag1 & - & - & $(-)$ & $(+)$ \\
\hline
\end{tabular}

Source: author.

Firm size has significant negative impact on firm performance except on ROA, and firm age has a negative impact on firm performance. Furthermore, firm size, leverage and firm age have significant negative impacts on firm performance, while CAPEX, which refers to investment opportunities, has significant positive impact. Using the Market-to-book ratio as a firm performance measure, the impacts are similar except for the effect of leverage. Using TSR as the firm performance measure, the variables have fewer significant effects, but the three main independent variables have a similar impact on firm performance as in the case of the Tobin's Q and MB models. The main difference is that only the interaction term between board size and firm size has a significant impact on firm performance.

\subsection{Dynamic panel regression}

Result from the dynamic panel regression models are similar to the fixed effects results: the same three variables have the same impact on firm performance in each firm performance measure.

In these models, the management board has a significant positive impact on firm market and operational performance, while the interaction term between management board size and firm size has a significant negative impact. The outside director ratio has a significant positive impact on firm performance in case of Tobin's Q and the Market-to-book ratio and positive in case of total shareholder return and ROA. The effects of variables in the models with Tobin's Q and MB are the same. Firm size, CAPEX and one-tiered management have a significant positive impact on firm performance, and so does firm age. The first lag of cash has a significant negative impact, 
Table 8. Signs of the independent variables

\begin{tabular}{|c|c|c|c|c|}
\hline & Tobin's Q & MB & TSR & ROA \\
\hline Lag 1 of dependent variables & + & + & - & + \\
\hline Log Boardsize & + & + & + & + \\
\hline Log Boardsize*Firmsize & - & - & - & - \\
\hline Outside director ratio & + & + & $(+)$ & $(+)$ \\
\hline Log Boardsize*Outside director & $(-)$ & $(-)$ & $(-)$ & $(+)$ \\
\hline Firmsize & - & - & - & + \\
\hline Net Fixed Assets & $(-)$ & $(-)$ & $(+)$ & - \\
\hline Leverage & $(-)$ & $(-)$ & + & - \\
\hline CAPEX & - & - & - & + \\
\hline One-tiered_management & - & - & $(+)$ & - \\
\hline Minority & $(-)$ & $(-)$ & $(-)$ & + \\
\hline Age & + & + & + & $(-)$ \\
\hline Volatility & $(-)$ & $(-)$ & $(+)$ & $(+)$ \\
\hline LogBoardsize*Leverage & $(-)$ & $(-)$ & + & + \\
\hline Log Boardsize*Cash lag1 & + & + & $(+)$ & $(+)$ \\
\hline Cash lag1 & - & - & $(-)$ & $(-)$ \\
\hline
\end{tabular}

Source: author.

while the management board size multiplied by firm size interaction term has a significant positive impact on firm performance.

The negative sign of the first lag of TSR explains the phenomenon of the negative autocorrelation of share returns (Table 8).

Comparing fixed effect models to dynamic panel regression models, it can be determined that management board size has a significant positive impact on firm performance, but if this variable is interacted with firm size, this effect is significantly negative. The impact of firm size on firm performance is the same in fixed effect and in dynamic panel regression models. Firm size has a significant negative impact on market performance, but positive impact on operational performance. However, firm age has a different effect: according to the dynamic regression models, it has a significant positive impact on market performance, the fixed effects models show a negative effect.

Testing the hypotheses, $\mathrm{H} 1$ is not supported, but $\mathrm{H} 2$ is. Controlling individual firm characteristics in firm fixed effects or in dynamic panel regression models, the impact of management board size on firm market performance is the opposite as the pairwise correlations would indicate. In the case of firm operational measures, this individual firm characteristic does not matter. H3 is only supported in the dynamic regression models, but $\mathrm{H} 4$ is rejected. Moreover, the outside director ratio has a positive impact on firm operational performance according to both regression techniques. H5 is supported by both regression techniques. 


\section{CONCLUSIONS}

The paper has analysed the relationship between corporate governance characteristics and firm performance measures. In two-tiered corporate governance systems, there are two boards, the management board, consisting of the directors or top managers of the company, and the supervisory board, comprising individuals independent from the company. The management board is responsible for operating activities and strategic decision-making, and the supervisory board for monitoring the management board. Therefore, it can be a credible assumption that the sizes of these boards can have an impact on firm performance. Based on the results, the management board has a significant positive impact on both market and operational performance measures, but this effect is limited, which is shown by the significant negative sign of the interaction term between board size and firm size. Firm performance cannot be improved if management board size increases along with firm size. The outside director ratio also has a positive impact on a firm's performance measures in dynamic regression models and this effect is significant for Tobin's Q and the market-to-book value ratio. The interaction term between management board size and cash have the same effect on firm performance as the outside director ratio. These results indicate that larger cash can have a disciplining effect on the management board.

\section{FUNDING}

This research was supported by the Higher Education Institutional Excellence Program of the Ministry for Innovation and Technology in the framework of the 'Financial and Public Services' research project (reference number: NKFIH-1163-10/2019) at Corvinus University of Budapest.

\section{REFERENCES}

Agrawal, A. - Knoeber, C.R. (2012): Corporate Governance and Firm Performance. In: Thomas, C. R. - Shughart, W. F. (eds): Oxford Handbook in Managerial Economics. New York: Oxford University Press, Ch. 26.

Al-Matari, E. M. - Al-Swidi, A. K. - Hanim, F. (2014): The Measurements of Firm Performance's Dimensions. Asian Journal of Finance \& Accounting 6(1): 24-49.

Bartlett, R.P. - Partnoy, F. (2018): The Misuse of Tobin's Q. https://papers.ssrn.com/sol3/papers.cfm? abstract_id $=3118020$, accessed 09/03/2020.

Beiner, S. - Drobetz, W. - Schmid, F. - Zimmermann, H. (2004): Is board size an independent corporate governance mechanism? Kyklos 57: 327-356.

Beiner, S. - Drobetz, W. - Schmid, M. M. - Zimmermann, H. (2006): An integrated framework of corporate governance and firm valuation. European Financial Management 12: 249-283.

Berle, A. A. - Means, G. (1932): The Modern Corporation and Private Property. New Jersey: Transaction Publishers.

Bozec, R. (2005): Boards of directors, market discipline and firm performance. Journal of Business Finance \& Accounting 32: 1921-1960.

Cheng, S. - Evans, J. H. - Nagarajan, N. (2008): Board size and firm performance: the moderating effects of the market for corporate control. Review of Quantitative, Finance and Accounting 31(2): 121-145. 
Chung, K. H. - Pruitt, S. W. (1994): A Simple Approximation of Tobin's Q. Financial Management, Venture Capital Special Issue 23(3): 70-74.

Coles, J. L. - Daniel, N. D. - Naveen, L. (2008): Boards: Does one size fit all? Journal of Financial Economics 87(2): 329-356.

Commonsense Principles 2.0 (2018): A Blueprint for U.S. Corporate Governance? https://www. governanceprinciples.org/wp-content/uploads/2018/10/CommonsensePrinciples2.0.pdf, accessed 09/ 03/2020.

Conyon, M. J. - Peck, S. I. (1998): Board size and corporate performance: Evidence from European countries. The European Journal of Finance 4: 291-304.

Dalton, D. R. - Daily, C. M. - Johnson, J. L. - Ellstrand, A. E. (1999): Number of directors and financial performance: A meta-analysis. Academy of Management Journal 42: 674-686.

Dobák, M. - Steger, T. (2003): Corporate Governance in Central and Eastern Europe - An introductory review. Journal for East European Management Studies 8(3): 223-235.

Dobija, D. - Kravchenko, G. (2017): Supervisory Board Composition and Firm Financial Performance: A Case of Companies Listed on the Warsaw Stock Exchange, Journal of Management and Business Administration 25(4): 75-95.

Dybvig, P. H. - Warachka, M. (2010): Tobin's Q Does Not Measure Firm Performance: Theory, Empirics, and Alternative Measures. https://papers.ssrn.com/sol3/papers.cfm?abstract_id=1562444, accessed 09/ $03 / 2020$.

Eisenberg, T. - Sundgren, S. - Wells, M. T. (1998): Larger board size and decreasing firm value in small firms. Journal of Financial Economics 48(1): 35-54.

Guest, P. M. (2009): The Impact of Board Size on Firm Performance: Evidence from the UK, The European Journal of Finance, 15(4): 385-404.

Gugler, K. - Ivanova, N. - Zechner, J. (2014): Ownership and control in Central and Eastern Europe. Journal of Corporate Finance 26: 145-163.

Hagel, J. - Brown, J. S. - Samoylova, T. - Lui, M. (2013): Success or struggle: ROA as a true measure of business performance. Deloitte Center for the Edge, https:/www2.deloitte.com/content/dam/insights/ us/articles/success-or-struggle-roa-as-a-true-measure-of-business-performance/DUP505_ROA_ vFINAL2.pdf, accessed 09/03/2020.

Haniffa, R. - Hudaib, M. (2006): Corporate governance structure and performance of Malaysian listed companies. Journal of Business Finance \& Accounting 33:1034-1062.

Ionascu, M. - Ionascu, I. - Sacarin, M. - Minu, M. (2018): Women on Boards and Financial Performance: Evidence from a European Emerging Market. Sustainability 10(5).

Jensen, M. C. (1993): The modern industrial revolution, exit, and the failure of internal control systems. Journal of Finance 48: 831-880.

Jensen, M. C. - Meckling, W. H. (1976): Theory of the firm: Managerial behavior, agency costs and ownership structure. Journal of Financial Economics 3(4): 305-360.

Lipton, M. - Lorsch, J. W. (1992): A Modest Proposal Improved Corporate Governance. The Business Lawyer 48(1): 59-77.

Loderer, C. - Peyer, U. (2002): Board overlap, seat accumulation and share prices. European Financial Management 8: 165-192.

Mak, Y. T. - Kusnadi, Y. (2005): Size really matters: Further evidence on the negative relationship between board size and firm value. Pacific-Basin Finance Journal 13: 301-318.

Michelberger, K. (2016): Corporate Governance Effects on Firm Performance: A Literature Review. Regional Formation and Development Studies 20(3): 84-95. 
Moscu, R.-G. (2013): The Relationship between Firm Performance and Board Characteristics in Romania. International Journal of Academic Research in Economics and Management Sciences 2(1): 167-175.

Nguyen, P. R. - Nahid, T. - Zhao, R. (2015): Board Size and Firm Value: Evidence from Australia. University of Technology Sydney Business School Working Paper Series from Finance Discipline Group No. 182.

Postma, T. J. B. M. - van Ees, H. - Sterken, E. (2001): Board composition and firm performance in the Netherlands. Eastern Economic Journal 29(1): 41-58.

Shleifer, A. - Vishney, R. W. (1997): A Survey of Corporate Governance. Journal of Finance 52(2): 737-783.

Vafeas, N. (1999): Board meeting frequency and firm performance. Journal of Financial Economics 53:113-142.

Yermack, D. (1996): Higher market valuation of companies with a small board of directors. Journal of Financial Economics 40(2): 185-211.

Zahra, S. A. - Pearce, J. A. (1989): Boards of Directors and Corporate Financial Performance: A Review and Integrative Model. Journal of Management 15(2): 291-334.

Open Access: This is an open-access article distributed under the terms of the Creative Commons Attribution 4.0 International License (https://creativecommons.org/licenses/by/4.0), which permits unrestricted use, distribution, and reproduction in any medium, provided the original author and source are credited, a link to the CC License is provided, and changes - if any - are indicated. (SID_1) 
Table 9. Fixed effects panel regression models, dependent variable: Tobin's Q

\begin{tabular}{|c|c|c|c|c|c|c|}
\hline Variables & $\begin{array}{c}(1) \\
\text { Model } 1\end{array}$ & $\begin{array}{c}\text { (2) } \\
\text { Model } 2\end{array}$ & $\begin{array}{c}\text { (3) } \\
\text { Model } 3\end{array}$ & $\begin{array}{c}(4) \\
\text { Model } 4\end{array}$ & $\begin{array}{c}\text { (5) } \\
\text { Model } 5\end{array}$ & $\begin{array}{c}(6) \\
\text { Model } 6\end{array}$ \\
\hline Log Boardsize & $\begin{array}{c}0.112 * * \\
(0.0464)\end{array}$ & $\begin{array}{l}-0.00846 \\
(0.0756)\end{array}$ & $\begin{array}{l}0.407^{* * *} \\
(0.157)\end{array}$ & $\begin{array}{l}0.645^{* *} \\
(0.295)\end{array}$ & $\begin{array}{l}0.437^{* * *} \\
(0.158)\end{array}$ & $\begin{array}{c}0.359 * * \\
(0.169)\end{array}$ \\
\hline $\begin{array}{l}\text { Log Boardsize* } \\
\text { Firmsize }\end{array}$ & & & $\begin{array}{l}-0.0868^{* * *} \\
(0.0288)\end{array}$ & $\begin{array}{l}-0.0944 * * * \\
(0.0299)\end{array}$ & $\begin{array}{l}-0.0778 * * * \\
(0.0294)\end{array}$ & $\begin{array}{l}-0.0859 * * * \\
(0.0297)\end{array}$ \\
\hline \multirow[t]{2}{*}{ Ouside director ratio } & & $-0.716^{* *}$ & $-0.663 * *$ & -0.292 & $-0.622 *$ & -0.533 \\
\hline & & $(0.335)$ & $(0.335)$ & $(0.513)$ & $(0.336)$ & (0.339) \\
\hline $\begin{array}{l}\text { Log Boardsize* } \\
\text { Outside director }\end{array}$ & & & & $\begin{array}{l}-0.279 \\
(0.293)\end{array}$ & & \\
\hline \multirow[t]{2}{*}{ Firmsize } & $-0.248^{* * *}$ & $-0.249 * * *$ & $-0.143^{* * *}$ & $-0.135^{* * *}$ & $-0.162 * * *$ & $-0.127^{* *}$ \\
\hline & $(0.0355)$ & $(0.0355)$ & $(0.0500)$ & $(0.0506)$ & $(0.0515)$ & $(0.0517)$ \\
\hline \multirow[t]{2}{*}{$\begin{array}{c}\text { Net Fixed } \\
\text { Assets }\end{array}$} & $-0.248^{*}$ & -0.202 & -0.190 & -0.185 & -0.191 & -0.0237 \\
\hline & $(0.149)$ & $(0.150)$ & $(0.149)$ & $(0.149)$ & $(0.149)$ & $(0.155)$ \\
\hline \multirow[t]{2}{*}{ Leverage } & $-0.504 * * *$ & $-0.511 * * *$ & $-0.534^{* * *}$ & $-0.533^{* * *}$ & -0.0346 & $-0.501 * * *$ \\
\hline & $(0.154)$ & $(0.154)$ & $(0.153)$ & $(0.153)$ & $(0.350)$ & $(0.153)$ \\
\hline \multirow[t]{2}{*}{ CAPEX } & $1.164 * * *$ & $1.163^{* * *}$ & $1.159 * * *$ & $1.158^{* * *}$ & $1.162 * * *$ & $0.748^{* * *}$ \\
\hline & $(0.261)$ & $(0.260)$ & $(0.260)$ & $(0.260)$ & $(0.260)$ & $(0.271)$ \\
\hline \multirow[t]{2}{*}{ One tiered management } & 0.216 & 0.225 & 0.207 & 0.182 & 0.214 & 0.205 \\
\hline & $(0.178)$ & $(0.177)$ & $(0.177)$ & $(0.179)$ & $(0.177)$ & $(0.177)$ \\
\hline \multirow[t]{2}{*}{ Minority } & -0.233 & -0.234 & -0.214 & -0.221 & -0.203 & -0.295 \\
\hline & $(0.209)$ & $(0.208)$ & $(0.208)$ & $(0.208)$ & $(0.208)$ & $(0.202)$ \\
\hline \multirow[t]{2}{*}{ Age } & $-0.0581 * * *$ & $-0.0572 * * *$ & $-0.0569 * * *$ & $-0.0567^{* * *}$ & $-0.0568 * * *$ & $0.0335^{* * *}$ \\
\hline & $(0.00599)$ & $(0.00598)$ & $(0.00597)$ & $(0.00597)$ & $(0.00597)$ & $(0.00616)$ \\
\hline
\end{tabular}


Table 9. Continued

\begin{tabular}{|c|c|c|c|c|c|c|}
\hline Variables & $\begin{array}{c}\text { (1) } \\
\text { Model } 1\end{array}$ & $\begin{array}{c}(2) \\
\text { Model } 2\end{array}$ & $\begin{array}{c}\text { (3) } \\
\text { Model } 3\end{array}$ & $\begin{array}{c}(4) \\
\text { Model } 4\end{array}$ & $\begin{array}{c}(5) \\
\text { Model } 5\end{array}$ & $\begin{array}{c}(6) \\
\text { Model } 6\end{array}$ \\
\hline \multirow[t]{2}{*}{ Volatility } & 0.000192 & 0.000196 & 0.000114 & 0.000185 & 0.000134 & -0.000189 \\
\hline & $(0.00155)$ & $(0.00155)$ & $(0.00155)$ & $(0.00155)$ & $(0.00154)$ & $(0.00149)$ \\
\hline \multirow[t]{2}{*}{ Log Boardsize*Leverage } & & & & & -0.405 & \\
\hline & & & & & $(0.255)$ & \\
\hline \multirow[t]{2}{*}{ Log Boardsize*Cash lag1 } & & & & & & $0.936 * * *$ \\
\hline & & & & & & $(0.352)$ \\
\hline \multirow[t]{2}{*}{ Cash lag1 } & & & & & & -0.384 \\
\hline & & & & & & $(0.473)$ \\
\hline \multirow[t]{2}{*}{ Constant } & $3.315^{* * *}$ & $3.874 * * *$ & $3.357^{* * *}$ & $3.047 * * *$ & $3.334 * * *$ & $1.957 * * *$ \\
\hline & $(0.176)$ & $(0.328)$ & $(0.369)$ & $(0.492)$ & $(0.369)$ & $(0.384)$ \\
\hline Observations & 2,281 & 2,278 & 2,278 & 2,278 & 2,278 & 2,118 \\
\hline Number of IndexF-test & 29718.53 & 29718.63 & 29718.48 & 29718.46 & 29718.50 & 29518.04 \\
\hline
\end{tabular}

Standard errors in parentheses and corrected for clustering at firm level. ${ }^{* *},{ }^{* *}, *$ indicate significance at the $1 \%, 5 \%$ and $10 \%$ level. Year fixed effects are not reported. 
Table 10. GMM-type dynamic panel regression models, dependent variable: Tobin's $Q$

\begin{tabular}{|c|c|c|c|c|c|c|}
\hline Variables & $\begin{array}{c}\text { (1) } \\
\text { Model } 1\end{array}$ & $\begin{array}{c}(2) \\
\text { Model } 2\end{array}$ & $\begin{array}{c}\text { (3) } \\
\text { Model } 3\end{array}$ & $\begin{array}{c}\text { (4) } \\
\text { Model } 4\end{array}$ & $\begin{array}{c}\text { (5) } \\
\text { Model } 5\end{array}$ & $\begin{array}{c}(6) \\
\text { Model } 6\end{array}$ \\
\hline \multirow[t]{2}{*}{ Lag1Tobin's Q } & $0.235^{* * *}$ & $0.235^{* * *}$ & $0.235^{* * *}$ & $0.234^{* * *}$ & $0.234^{* * *}$ & $0.233^{* * *}$ \\
\hline & $(0.0207)$ & $(0.0207)$ & $(0.0207)$ & $(0.0207)$ & $(0.0208)$ & $(0.0208)$ \\
\hline \multirow[t]{2}{*}{ Log Boardsize } & -0.0114 & 0.157 & $0.645^{* * *}$ & $0.919 * *$ & $0.650 * * *$ & $0.521 * *$ \\
\hline & $(0.0635)$ & $(0.106)$ & $(0.224)$ & $(0.436)$ & $(0.225)$ & $(0.227)$ \\
\hline \multirow[t]{2}{*}{ Log Boardsize*Firmsize } & & & $-0.105^{* *}$ & $-0.117 * *$ & $-0.101 * *$ & $-0.103^{* *}$ \\
\hline & & & $(0.0423)$ & $(0.0455)$ & $(0.0430)$ & $(0.0422)$ \\
\hline \multirow[t]{2}{*}{ Ouside director ratio } & & $0.868^{* *}$ & $0.895^{* *}$ & $1.300^{*}$ & $0.906^{* *}$ & $0.903^{* *}$ \\
\hline & & $(0.438)$ & $(0.438)$ & $(0.703)$ & $(0.439)$ & $(0.438)$ \\
\hline \multirow[t]{2}{*}{ Log Boardsize*Outside director } & & & & -0.297 & & \\
\hline & & & & $(0.404)$ & & \\
\hline Firmsize & $-0.618^{* * *}$ & $-0.617^{* * *}$ & $-0.491 * * *$ & $-0.479 * * *$ & $-0.496 * * *$ & $-0.491 * * *$ \\
\hline \multirow[t]{2}{*}{ Net Fixed Assets } & -0.0311 & -0.0255 & -0.0180 & -0.0203 & -0.0241 & -0.0565 \\
\hline & $(0.211)$ & $(0.211)$ & $(0.211)$ & $(0.211)$ & $(0.211)$ & $(0.211)$ \\
\hline \multirow[t]{2}{*}{ Leverage } & -0.159 & -0.171 & -0.184 & -0.182 & -0.0346 & -0.193 \\
\hline & $(0.195)$ & $(0.195)$ & $(0.195)$ & $(0.195)$ & $(0.443)$ & $(0.195)$ \\
\hline \multirow[t]{2}{*}{ CAPEX } & $-0.824 * *$ & $-0.814^{* *}$ & $-0.813^{* *}$ & $-0.813^{* *}$ & $-0.808 * *$ & $-0.793 * *$ \\
\hline & $(0.325)$ & $(0.325)$ & $(0.325)$ & $(0.325)$ & $(0.325)$ & $(0.330)$ \\
\hline \multirow[t]{2}{*}{ One tiered management } & $-0.607 * * *$ & $-0.593 * * *$ & $-0.614 * * *$ & $-0.647 * * *$ & $-0.613 * * *$ & $-0.566 * * *$ \\
\hline & $(0.199)$ & $(0.199)$ & $(0.199)$ & $(0.204)$ & $(0.199)$ & $(0.199)$ \\
\hline \multirow[t]{2}{*}{ Minority } & -0.112 & -0.110 & -0.0923 & -0.0978 & -0.0897 & -0.0974 \\
\hline & $(0.255)$ & $(0.255)$ & $(0.255)$ & $(0.255)$ & $(0.255)$ & $(0.256)$ \\
\hline \multirow[t]{2}{*}{ Age } & $0.0387^{* * *}$ & $0.0388 * * *$ & $0.0390 * * *$ & $0.0392 * * *$ & $0.0390 * * *$ & $0.0379 * * *$ \\
\hline & $(0.00516)$ & $(0.00517)$ & $(0.00516)$ & $(0.00517)$ & $(0.00516)$ & $(0.00517)$ \\
\hline
\end{tabular}


Table 10. Continued

\begin{tabular}{|c|c|c|c|c|c|c|}
\hline Variables & $\begin{array}{c}\text { (1) } \\
\text { Model } 1\end{array}$ & $\begin{array}{c}\text { (2) } \\
\text { Model } 2\end{array}$ & $\begin{array}{c}\text { (3) } \\
\text { Model } 3\end{array}$ & $\begin{array}{c}(4) \\
\text { Model } 4\end{array}$ & $\begin{array}{c}\text { (5) } \\
\text { Model } 5\end{array}$ & $\begin{array}{c}\text { (6) } \\
\text { Model } 6\end{array}$ \\
\hline \multirow[t]{2}{*}{ Volatility } & -0.000340 & -0.000378 & -0.000403 & -0.000372 & -0.000381 & -0.000446 \\
\hline & $(0.00153)$ & $(0.00153)$ & $(0.00153)$ & $(0.00153)$ & $(0.00153)$ & $(0.00153)$ \\
\hline \multirow[t]{2}{*}{ Log Boardsize*Leverage } & & & & & -0.126 & \\
\hline & & & & & $(0.336)$ & \\
\hline \multirow[t]{2}{*}{ Log Boardsize*Cash lag1 } & & & & & & $1.506 * * *$ \\
\hline & & & & & & $(0.454)$ \\
\hline \multirow[t]{2}{*}{ Cash lag1 } & & & & & & $-1.530 * *$ \\
\hline & & & & & & $(0.602)$ \\
\hline \multirow[t]{2}{*}{ Constant } & $3.694 * * *$ & $2.949 * * *$ & $2.380 * * *$ & $2.026 * * *$ & $2.375^{* * *}$ & $2.512 * * *$ \\
\hline & $(0.197)$ & $(0.425)$ & $(0.485)$ & $(0.684)$ & $(0.485)$ & $(0.487)$ \\
\hline Observations & 2,098 & 2,098 & 2,098 & 2,098 & 2,098 & 2,098 \\
\hline
\end{tabular}

Standard errors in parentheses and corrected for clustering at firm level. ${ }^{* *}, * *, *$ indicate significance at the $1 \%, 5 \%$ and $10 \%$ level. Year fixed effects are not reported. 
Table 11. Fixed effects panel regression models, dependent variable: Market-to-Book ratio

\begin{tabular}{|c|c|c|c|c|c|c|}
\hline Variables & $\begin{array}{c}\text { (1) } \\
\text { Model } 1\end{array}$ & $\begin{array}{c}\text { (2) } \\
\text { Model } 2\end{array}$ & $\begin{array}{c}\text { (3) } \\
\text { Model } 3\end{array}$ & $\begin{array}{c}(4) \\
\text { Model } 4\end{array}$ & $\begin{array}{c}\text { (5) } \\
\text { Model } 5\end{array}$ & $\begin{array}{c}(6) \\
\text { Model } 6\end{array}$ \\
\hline \multirow[t]{2}{*}{ Log Boardsize } & $0.303^{* * *}$ & 0.0364 & $0.728^{*}$ & 0.845 & $0.768^{* *}$ & 0.331 \\
\hline & $(0.113)$ & $(0.184)$ & $(0.383)$ & $(0.720)$ & $(0.385)$ & $(0.423)$ \\
\hline \multirow[t]{2}{*}{ Log Boardsize*Firmsize } & & & $-0.144 * *$ & $-0.148 * *$ & $-0.131 *$ & -0.112 \\
\hline & & & $(0.0701)$ & $(0.0727)$ & $(0.0715)$ & $(0.0744)$ \\
\hline \multirow[t]{2}{*}{ Outside director ratio } & & $-1.434^{*}$ & $-1.355^{*}$ & -1.172 & -1.299 & -1.354 \\
\hline & & $(0.814)$ & $(0.814)$ & $(1.254)$ & $(0.816)$ & $(0.852)$ \\
\hline \multirow[t]{2}{*}{ Log Boardsize*Outside director } & & & & -0.136 & & \\
\hline & & & & $(0.711)$ & & \\
\hline \multirow[t]{2}{*}{ Firmsize } & $-0.764 * * *$ & $-0.759 * * *$ & $-0.581 * * *$ & $-0.578 * * *$ & $-0.608 * * *$ & $-0.602 * * *$ \\
\hline & $(0.0871)$ & $(0.0870)$ & $(0.122)$ & $(0.124)$ & $(0.126)$ & $(0.129)$ \\
\hline Net Fixed Assets & -0.209 & -0.159 & -0.149 & -0.147 & -0.145 & 0.200 \\
\hline \multirow[t]{2}{*}{ Leverage } & $1.119 * * *$ & $1.126 * * *$ & $1.088 * * *$ & $1.089 * * *$ & $1.780 * *$ & $1.099 * * *$ \\
\hline & $(0.383)$ & $(0.382)$ & $(0.382)$ & $(0.382)$ & $(0.846)$ & $(0.396)$ \\
\hline \multirow[t]{2}{*}{ CAPEX } & $1.932 * * *$ & $1.915^{* * *}$ & $1.908 * * *$ & $1.907 * * *$ & $1.914 * * *$ & $1.220 *$ \\
\hline & $(0.634)$ & $(0.633)$ & $(0.632)$ & $(0.632)$ & $(0.632)$ & $(0.681)$ \\
\hline \multirow[t]{2}{*}{ One-tiered_management } & 0.416 & 0.460 & 0.432 & 0.418 & 0.442 & 0.533 \\
\hline & $(0.431)$ & $(0.430)$ & $(0.430)$ & $(0.436)$ & $(0.430)$ & $(0.439)$ \\
\hline \multirow[t]{2}{*}{ Minority } & 0.0403 & 0.00732 & -0.000137 & -0.000710 & 0.0200 & 0.0271 \\
\hline & (0.599) & $(0.597)$ & $(0.597)$ & $(0.597)$ & $(0.597)$ & $(0.607)$ \\
\hline \multirow[t]{2}{*}{ Age } & $-0.0844 * * *$ & $-0.0817 * * *$ & $-0.0810 * * *$ & $-0.0809 * * *$ & $-0.0809 * * *$ & $0.0930 * * *$ \\
\hline & $(0.0144)$ & $(0.0144)$ & $(0.0144)$ & $(0.0144)$ & $(0.0144)$ & $(0.0154)$ \\
\hline \multirow[t]{2}{*}{ Volatility } & 0.000233 & 0.000227 & $8.46 e-05$ & 0.000119 & 0.000114 & -0.000311 \\
\hline & $(0.00373)$ & $(0.00372)$ & $(0.00372)$ & $(0.00373)$ & $(0.00372)$ & $(0.00369)$ \\
\hline
\end{tabular}


Table 11. Continued

\begin{tabular}{|c|c|c|c|c|c|c|}
\hline Variables & $\begin{array}{c}(1) \\
\text { Model } 1\end{array}$ & $\begin{array}{c}\text { (2) } \\
\text { Model } 2\end{array}$ & $\begin{array}{c}\text { (3) } \\
\text { Model } 3\end{array}$ & $\begin{array}{c}(4) \\
\text { Model } 4\end{array}$ & $\begin{array}{c}\text { (5) } \\
\text { Model } 5\end{array}$ & $\begin{array}{c}(6) \\
\text { Model } 6\end{array}$ \\
\hline \multirow[t]{2}{*}{ LogBoardsize*Leverage } & & & & & -0.573 & \\
\hline & & & & & $(0.625)$ & \\
\hline \multirow[t]{2}{*}{ Log Boardsize*Cash lag1 } & & & & & & $2.372 * * *$ \\
\hline & & & & & & $(0.878)$ \\
\hline \multirow[t]{2}{*}{ Cash lag1 } & & & & & & $-2.099 *$ \\
\hline & & & & & & $(1.182)$ \\
\hline \multirow[t]{2}{*}{ Constant } & $6.101 * * *$ & $7.214 * * *$ & $6.361 * * *$ & $6.208 * * *$ & $6.321 * * *$ & $4.257 * * *$ \\
\hline & $(0.430)$ & $(0.793)$ & $(0.894)$ & (1.198) & $(0.895)$ & $(0.958)$ \\
\hline Observations & 2,260 & 2,257 & 2,257 & 2,257 & 2,257 & 2,098 \\
\hline R-squared & 0.129 & 0.127 & 0.129 & 0.129 & 0.129 & 0.075 \\
\hline Number of IndexF-test & 296 & 296 & 296 & 296 & 296 & 294 \\
\hline
\end{tabular}

Standard errors in parentheses and corrected for clustering at firm level. ${ }^{* * *},{ }^{* *},{ }^{*}$ indicate significance at the $1 \%, 5 \%$ and $10 \%$ level. Year fixed effects are not reported. 
Table 12. GMM-type dynamic panel regression models, dependent variable: Market-to-Book ratio

\begin{tabular}{|c|c|c|c|c|c|c|}
\hline Variables & $\begin{array}{c}\text { (1) } \\
\text { Model } 1\end{array}$ & $\begin{array}{c}\text { (2) } \\
\text { Model } 2\end{array}$ & $\begin{array}{c}\text { (3) } \\
\text { Model } 3\end{array}$ & $\begin{array}{c}(4) \\
\text { Model } 4\end{array}$ & $\begin{array}{c}\text { (5) } \\
\text { Model } 5\end{array}$ & $\begin{array}{c}(6) \\
\text { Model } 6\end{array}$ \\
\hline \multirow[t]{2}{*}{ Lag $1 \mathrm{MB}$} & $0.235^{* * *}$ & $0.235^{* * *}$ & $0.235^{* * *}$ & $0.234^{* * *}$ & $0.234 * * *$ & $0.233^{* * *}$ \\
\hline & $(0.0207)$ & $(0.0207)$ & $(0.0207)$ & $(0.0207)$ & $(0.0208)$ & $(0.0208)$ \\
\hline \multirow[t]{2}{*}{ Log Boardsize } & -0.0114 & 0.157 & $0.645^{* * *}$ & $0.919 * *$ & $0.650 * * *$ & $0.521 * *$ \\
\hline & $(0.0635)$ & $(0.106)$ & $(0.224)$ & $(0.436)$ & $(0.225)$ & $(0.227)$ \\
\hline \multirow[t]{2}{*}{ Log Boardsize*Firmsize } & & & $-0.105^{* *}$ & $-0.117^{* *}$ & $-0.101^{* *}$ & $-0.103^{* *}$ \\
\hline & & & $(0.0423)$ & $(0.0455)$ & $(0.0430)$ & $(0.0422)$ \\
\hline \multirow[t]{2}{*}{ Ouside director ratio } & & $0.868 * *$ & $0.895^{* *}$ & $1.300^{*}$ & $0.906 * *$ & $0.903^{* *}$ \\
\hline & & $(0.438)$ & $(0.438)$ & $(0.703)$ & $(0.439)$ & $(0.438)$ \\
\hline \multirow[t]{2}{*}{ Log Boardsize*Outside director } & & & & -0.297 & & \\
\hline & & & & $(0.404)$ & & \\
\hline Firmsize & $-0.618^{* * *}$ & $-0.617^{* * *}$ & $-0.491 * * *$ & $-0.479 * * *$ & $-0.496 * * *$ & $-0.491 * * *$ \\
\hline \multirow[t]{2}{*}{ Net Fixed Assets } & -0.0311 & -0.0255 & -0.0180 & -0.0203 & -0.0241 & -0.0565 \\
\hline & $(0.211)$ & $(0.211)$ & $(0.211)$ & $(0.211)$ & $(0.211)$ & $(0.211)$ \\
\hline \multirow[t]{2}{*}{ Leverage } & -0.159 & -0.171 & -0.184 & -0.182 & -0.0346 & -0.193 \\
\hline & $(0.195)$ & $(0.195)$ & $(0.195)$ & $(0.195)$ & $(0.443)$ & $(0.195)$ \\
\hline \multirow[t]{2}{*}{ CAPEX } & $-0.824^{* *}$ & $-0.814^{* *}$ & $-0.813^{* *}$ & $-0.813^{* *}$ & $-0.808^{* *}$ & $-0.793^{* *}$ \\
\hline & $(0.325)$ & $(0.325)$ & $(0.325)$ & $(0.325)$ & $(0.325)$ & $(0.330)$ \\
\hline \multirow[t]{2}{*}{ One tiered management } & $-0.607 * * *$ & $-0.593^{* * *}$ & $-0.614 * * *$ & $-0.647 * * *$ & $-0.613^{* * *}$ & $-0.566 * * *$ \\
\hline & $(0.199)$ & $(0.199)$ & $(0.199)$ & $(0.204)$ & $(0.199)$ & (0.199) \\
\hline \multirow[t]{2}{*}{ Minority } & -0.112 & -0.110 & -0.0923 & -0.0978 & -0.0897 & -0.0974 \\
\hline & $(0.255)$ & $(0.255)$ & $(0.255)$ & $(0.255)$ & $(0.255)$ & $(0.256)$ \\
\hline \multirow[t]{2}{*}{ Age } & $0.0387^{* * *}$ & $0.0388^{* * *}$ & $0.0390 * * *$ & $0.0392 * * *$ & $0.0390 * * *$ & $0.0379 * * *$ \\
\hline & $(0.00516)$ & $(0.00517)$ & $(0.00516)$ & $(0.00517)$ & $(0.00516)$ & $(0.00517)$ \\
\hline
\end{tabular}


Table 12. Continued

\begin{tabular}{|c|c|c|c|c|c|c|}
\hline Variables & $\begin{array}{c}\text { (1) } \\
\text { Model } 1\end{array}$ & $\begin{array}{c}(2) \\
\text { Model } 2\end{array}$ & $\begin{array}{c}\text { (3) } \\
\text { Model } 3\end{array}$ & $\begin{array}{c}\text { (4) } \\
\text { Model } 4\end{array}$ & $\begin{array}{c}\text { (5) } \\
\text { Model } 5\end{array}$ & $\begin{array}{c}(6) \\
\text { Model } 6\end{array}$ \\
\hline \multirow[t]{2}{*}{ Volatility } & -0.000340 & -0.000378 & -0.000403 & -0.000372 & -0.000381 & -0.000446 \\
\hline & $(0.00153)$ & $(0.00153)$ & $(0.00153)$ & $(0.00153)$ & $(0.00153)$ & $(0.00153)$ \\
\hline \multirow[t]{2}{*}{ Log Boardsize*Leverage } & & & & & -0.126 & \\
\hline & & & & & $(0.336)$ & \\
\hline \multirow[t]{2}{*}{ Log Boardsize*Cash lag1 } & & & & & & $1.506 * * *$ \\
\hline & & & & & & $(0.454)$ \\
\hline \multirow[t]{2}{*}{ Cash lag1 } & & & & & & $-1.530 * *$ \\
\hline & & & & & & $(0.602)$ \\
\hline \multirow[t]{2}{*}{ Constant } & $3.694 * * *$ & $2.949 * * *$ & $2.380 * * *$ & $2.026 * * *$ & $2.375^{* * *}$ & $2.512 * * *$ \\
\hline & $(0.197)$ & $(0.425)$ & $(0.485)$ & $(0.684)$ & $(0.485)$ & $(0.487)$ \\
\hline Observations & 2,098 & 2,098 & 2,098 & 2,098 & 2,098 & 2,098 \\
\hline
\end{tabular}

Standard errors in parentheses and corrected for clustering at firm level. ${ }^{* *},{ }^{* *},{ }^{*}$ indicate significance at the $1 \%, 5 \%$ and $10 \%$ level. Year fixed effects are not reported. 
Table 13. Fixed effects panel regression models, dependent variable: TSR

\begin{tabular}{|c|c|c|c|c|c|c|}
\hline Variables & $\begin{array}{c}\text { (1) } \\
\text { Model } 1\end{array}$ & $\begin{array}{c}(2) \\
\text { Model } 2\end{array}$ & $\begin{array}{c}\text { (3) } \\
\text { Model } 3\end{array}$ & $\begin{array}{c}\text { (4) } \\
\text { Model } 4\end{array}$ & $\begin{array}{c}(5) \\
\text { Model } 5\end{array}$ & $\begin{array}{c}\text { (6) } \\
\text { Model } 6\end{array}$ \\
\hline \multirow[t]{2}{*}{ Log Boardsize } & -0.0582 & $-0.151^{*}$ & 0.170 & 0.0340 & 0.175 & 0.187 \\
\hline & $(0.0514)$ & $(0.0840)$ & $(0.174)$ & $(0.327)$ & $(0.175)$ & $(0.192)$ \\
\hline \multirow[t]{2}{*}{ Log Boardsize*Firmsize } & & & $-0.0670^{* *}$ & $-0.0627^{*}$ & $-0.0652 * *$ & $-0.0713^{* *}$ \\
\hline & & & $(0.0318)$ & $(0.0331)$ & $(0.0325)$ & $(0.0339)$ \\
\hline \multirow[t]{2}{*}{ Outside director ratio } & & -0.502 & -0.460 & -0.670 & -0.452 & -0.183 \\
\hline & & $(0.373)$ & $(0.373)$ & $(0.569)$ & $(0.374)$ & $(0.393)$ \\
\hline \multirow[t]{2}{*}{ Log Boardsize*Outside director } & & & & 0.159 & & \\
\hline & & & & $(0.324)$ & & \\
\hline \multirow[t]{2}{*}{ Firmsize } & $-0.175^{* * *}$ & $-0.177^{* * *}$ & $-0.0964^{*}$ & $-0.101^{*}$ & $-0.100 *$ & -0.0662 \\
\hline & $(0.0387)$ & $(0.0388)$ & $(0.0545)$ & $(0.0553)$ & $(0.0563)$ & $(0.0582)$ \\
\hline Net Fixed Assets & $-0.756^{* * *}$ & $-0.736 * * *$ & $-0.726 * * *$ & $-0.728 * * *$ & $-0.726 * * *$ & $-0.624 * * *$ \\
\hline \multirow[t]{2}{*}{ Leverage } & $0.456 * * *$ & $0.455^{* * *}$ & $0.435^{* *}$ & $0.434 * *$ & 0.536 & $0.373^{* *}$ \\
\hline & $(0.169)$ & $(0.169)$ & $(0.169)$ & $(0.169)$ & $(0.387)$ & $(0.176)$ \\
\hline \multirow[t]{2}{*}{ CAPEX } & 0.237 & 0.226 & 0.224 & 0.225 & 0.225 & 0.458 \\
\hline & $(0.288)$ & $(0.289)$ & $(0.288)$ & $(0.288)$ & $(0.288)$ & $(0.312)$ \\
\hline \multirow[t]{2}{*}{ One-tiered_management } & 0.129 & 0.139 & 0.129 & 0.144 & 0.130 & 0.158 \\
\hline & $(0.193)$ & $(0.193)$ & $(0.193)$ & $(0.196)$ & $(0.193)$ & $(0.198)$ \\
\hline \multirow[t]{2}{*}{ Minority } & 0.00185 & 0.00569 & 0.0224 & 0.0265 & 0.0245 & -0.0162 \\
\hline & $(0.232)$ & $(0.232)$ & $(0.232)$ & $(0.232)$ & $(0.232)$ & $(0.234)$ \\
\hline \multirow[t]{2}{*}{ Age } & -0.00332 & -0.00288 & -0.00255 & -0.00262 & -0.00253 & $0.0980 * * *$ \\
\hline & $(0.00665)$ & $(0.00666)$ & $(0.00666)$ & $(0.00666)$ & $(0.00666)$ & $(0.00709)$ \\
\hline \multirow[t]{2}{*}{ Volatility } & 0.000451 & 0.000458 & 0.000396 & 0.000356 & 0.000400 & 0.000197 \\
\hline & $(0.00173)$ & $(0.00173)$ & $(0.00173)$ & $(0.00173)$ & $(0.00173)$ & $(0.00172)$ \\
\hline
\end{tabular}


Table 13. Continued

\begin{tabular}{|c|c|c|c|c|c|c|}
\hline Variables & $\begin{array}{c}\text { (1) } \\
\text { Model } 1\end{array}$ & $\begin{array}{c}\text { (2) } \\
\text { Model } 2\end{array}$ & $\begin{array}{c}\text { (3) } \\
\text { Model } 3\end{array}$ & $\begin{array}{c}\text { (4) } \\
\text { Model } 4\end{array}$ & $\begin{array}{c}(5) \\
\text { Model } 5\end{array}$ & $\begin{array}{c}(6) \\
\text { Model } 6\end{array}$ \\
\hline \multirow[t]{2}{*}{ Log Boardsize*Leverage } & & & & & -0.0815 & \\
\hline & & & & & $(0.281)$ & \\
\hline Log Boardsize*Cash lag1 & & & & & & $0.457(0.405)$ \\
\hline Cash lag1 & & & & & & $-0.576(0.545)$ \\
\hline \multirow[t]{2}{*}{ Constant } & $1.332 * * *$ & $1.751 * * *$ & $1.357^{* * *}$ & $1.534 * * *$ & $1.353 * * *$ & -0.312 \\
\hline & $(0.193)$ & $(0.363)$ & $(0.408)$ & $(0.545)$ & $(0.408)$ & $(0.439)$ \\
\hline Observations & 2,300 & 2,297 & 2,297 & 2,297 & 2,297 & 2,133 \\
\hline R-squared & 0.257 & 0.258 & 0.259 & 0.259 & 0.259 & 0.274 \\
\hline Number of IndexF-test & 29718.53 & 29718.63 & 29718.48 & 29718.46 & 29718.50 & 29518.04 \\
\hline
\end{tabular}

Standard errors in parentheses and corrected for clustering at firm level. ${ }^{* *},{ }^{* *},{ }^{*}$ indicate significance at the $1 \%, 5 \%$ and $10 \%$ level. Year fixed effects are not reported. 
Table 14. GMM-type dynamic panel regression models, dependent variable: TSR

\begin{tabular}{|c|c|c|c|c|c|c|}
\hline Variables & $\begin{array}{c}\text { (1) } \\
\text { Model } 1\end{array}$ & $\begin{array}{c}\text { (2) } \\
\text { Model } 2\end{array}$ & $\begin{array}{c}\text { (3) } \\
\text { Model } 3\end{array}$ & $\begin{array}{c}(4) \\
\text { Model } 4\end{array}$ & $\begin{array}{c}\text { (5) } \\
\text { Model } 5\end{array}$ & $\begin{array}{c}(6) \\
\text { Model } 6\end{array}$ \\
\hline \multirow[t]{2}{*}{ Lag1TSR } & $-0.0700^{* * *}$ & $-0.0706 * * *$ & $-0.0736 * * *$ & $-0.0739 * * *$ & $-0.0716 * * *$ & $-0.0717 * * *$ \\
\hline & $(0.0194)$ & $(0.0194)$ & $(0.0194)$ & $(0.0194)$ & $(0.0195)$ & $(0.0195)$ \\
\hline \multirow[t]{2}{*}{ Log Boardsize } & -0.0744 & -0.0257 & $1.092 * * *$ & $1.496 * *$ & $1.027^{* * *}$ & $1.039 * * *$ \\
\hline & $(0.0930)$ & $(0.154)$ & $(0.319)$ & $(0.651)$ & (0.321) & (0.329) \\
\hline \multirow[t]{2}{*}{ Log Boardsize*Firmsize } & & & $-0.238 * * *$ & $-0.256 * * *$ & $-0.252 * * *$ & $-0.228 * * *$ \\
\hline & & & $(0.0595)$ & $(0.0651)$ & $(0.0604)$ & $(0.0603)$ \\
\hline \multirow[t]{2}{*}{ Ouside director ratio } & & 0.261 & 0.328 & 0.929 & 0.232 & 0.450 \\
\hline & & $(0.653)$ & $(0.652)$ & (1.056) & $(0.655)$ & (0.659) \\
\hline \multirow[t]{2}{*}{ Log Boardsize*0utside director } & & & & -0.434 & & \\
\hline & & & & $(0.599)$ & & \\
\hline Firmsize & -0.0744 & -0.0760 & $0.203^{* *}$ & $0.223 * *$ & $0.224 * *$ & $0.188^{* *}$ \\
\hline \multirow[t]{2}{*}{ Net Fixed Assets } & 0.183 & 0.178 & 0.247 & 0.242 & 0.243 & 0.218 \\
\hline & $(0.286)$ & $(0.286)$ & $(0.286)$ & $(0.286)$ & $(0.286)$ & $(0.290)$ \\
\hline \multirow[t]{2}{*}{ Leverage } & $0.543^{*}$ & $0.542 *$ & $0.506^{*}$ & $0.509 *$ & -0.423 & $0.495^{*}$ \\
\hline & $(0.281)$ & $(0.281)$ & $(0.281)$ & $(0.281)$ & $(0.629)$ & $(0.283)$ \\
\hline \multirow[t]{2}{*}{ CAPEX } & $-1.878^{* * *}$ & $-1.878^{* * *}$ & $-1.873^{* * *}$ & $-1.865^{* * *}$ & $-1.842 * * *$ & $-1.887 * * *$ \\
\hline & $(0.477)$ & $(0.477)$ & $(0.476)$ & $(0.476)$ & $(0.477)$ & $(0.490)$ \\
\hline \multirow[t]{2}{*}{ One tiered management } & 0.191 & 0.205 & 0.133 & 0.0656 & 0.113 & 0.208 \\
\hline & $(0.275)$ & $(0.275)$ & $(0.275)$ & $(0.287)$ & $(0.275)$ & $(0.280)$ \\
\hline \multirow[t]{2}{*}{ Minority } & -0.189 & -0.195 & -0.158 & -0.166 & -0.184 & -0.156 \\
\hline & $(0.371)$ & $(0.371)$ & $(0.370)$ & $(0.370)$ & $(0.371)$ & $(0.376)$ \\
\hline \multirow[t]{2}{*}{ Age } & 0.0106 & 0.0106 & $0.0134^{*}$ & $0.0138^{*}$ & $0.0137^{*}$ & 0.0115 \\
\hline & $(0.00749)$ & $(0.00748)$ & $(0.00749)$ & $(0.00752)$ & $(0.00750)$ & $(0.00757)$ \\
\hline
\end{tabular}


Table 14. Continued

\begin{tabular}{|c|c|c|c|c|c|c|}
\hline Variables & $\begin{array}{c}\text { (1) } \\
\text { Model } 1\end{array}$ & $\begin{array}{c}\text { (2) } \\
\text { Model } 2\end{array}$ & $\begin{array}{c}\text { (3) } \\
\text { Model } 3\end{array}$ & $\begin{array}{c}(4) \\
\text { Model } 4\end{array}$ & $\begin{array}{c}\text { (5) } \\
\text { Model } 5\end{array}$ & $\begin{array}{c}\text { (6) } \\
\text { Model } 6\end{array}$ \\
\hline \multirow[t]{2}{*}{ Volatility } & 0.00115 & 0.00112 & 0.000987 & 0.00108 & 0.000984 & 0.000972 \\
\hline & $(0.00222)$ & $(0.00222)$ & $(0.00222)$ & $(0.00222)$ & $(0.00222)$ & $(0.00222)$ \\
\hline \multirow[t]{2}{*}{ Log Boardsize*Leverage } & & & & & $0.771^{*}$ & \\
\hline & & & & & $(0.466)$ & \\
\hline \multirow[t]{2}{*}{ Log Boardsize*Cash lag1 } & & & & & & 0.407 \\
\hline & & & & & & $(0.696)$ \\
\hline \multirow[t]{2}{*}{ Cash lag1 } & & & & & & -0.762 \\
\hline & & & & & & $(0.943)$ \\
\hline \multirow[t]{2}{*}{ Constant } & $0.424^{*}$ & 0.214 & $-1.102 *$ & -1.641 & -0.979 & -1.053 \\
\hline & $(0.236)$ & $(0.576)$ & $(0.667)$ & $(1.008)$ & $(0.671)$ & $(0.683)$ \\
\hline Observations & 2,069 & 2,069 & 2,069 & 2,069 & 2,069 & 2,048 \\
\hline Number of Index & 297 & 297 & 297 & 297 & 297 & 295 \\
\hline
\end{tabular}

Standard errors in parentheses and corrected for clustering at firm level. ${ }^{* *},{ }^{* *},{ }^{*}$ indicate significance at the $1 \%, 5 \%$ and $10 \%$ level. Year fixed effects are not reported. 
Table 15. Fixed effects panel regression models, dependent variable: ROA

\begin{tabular}{|c|c|c|c|c|c|c|}
\hline Variables & $\begin{array}{c}\text { (1) } \\
\text { Model } 1\end{array}$ & $\begin{array}{c}\text { (2) } \\
\text { Model } 2\end{array}$ & $\begin{array}{c}\text { (3) } \\
\text { Model } 3\end{array}$ & $\begin{array}{c}\text { (4) } \\
\text { Model } 4\end{array}$ & $\begin{array}{c}\text { (5) } \\
\text { Model } 5\end{array}$ & $\begin{array}{c}(6) \\
\text { Model } 6\end{array}$ \\
\hline \multirow[t]{2}{*}{ Log Boardsize } & -0.00204 & 0.000386 & 0.0369 & 0.0472 & 0.0333 & 0.0387 \\
\hline & $(0.00681)$ & $(0.0111)$ & $(0.0231)$ & $(0.0434)$ & $(0.0232)$ & $(0.0260)$ \\
\hline \multirow[t]{2}{*}{ Log Boardsize*Firmsize } & & & $-0.00763^{*}$ & $-0.00796 *$ & $-0.00889 * *$ & -0.00631 \\
\hline & & & $(0.00422)$ & $(0.00439)$ & $(0.00431)$ & $(0.00458)$ \\
\hline \multirow[t]{2}{*}{ Outside director ratio } & & 0.00920 & 0.0139 & 0.0299 & 0.00888 & 0.0485 \\
\hline & & $(0.0495)$ & $(0.0496)$ & $(0.0756)$ & $(0.0497)$ & $(0.0530)$ \\
\hline \multirow[t]{2}{*}{ Log Boardsize*0utside director } & & & & -0.0121 & & \\
\hline & & & & $(0.0431)$ & & \\
\hline \multirow[t]{2}{*}{ Firmsize } & 0.000868 & 0.000937 & 0.0101 & 0.0105 & $0.0129 *$ & 0.00279 \\
\hline & $(0.00513)$ & $(0.00514)$ & $(0.00724)$ & $(0.00734)$ & $(0.00747)$ & $(0.00785)$ \\
\hline Net Fixed Assets & $-0.210 * * *$ & $-0.209 * * *$ & $-0.208 * * *$ & $-0.208 * * *$ & $-0.208 * * *$ & $-0.217 * * *$ \\
\hline \multirow[t]{2}{*}{ Leverage } & -0.0365 & $-0.0375^{*}$ & $-0.0397 *$ & $-0.0396 *$ & $-0.107^{* *}$ & -0.0194 \\
\hline & $(0.0224)$ & $(0.0225)$ & $(0.0225)$ & $(0.0225)$ & $(0.0513)$ & $(0.0237)$ \\
\hline \multirow[t]{2}{*}{ CAPEX } & $0.176^{* * *}$ & $0.177^{* * *}$ & $0.177^{* * *}$ & $0.177 * * *$ & $0.176^{* * *}$ & $0.167 * * *$ \\
\hline & $(0.0382)$ & $(0.0383)$ & $(0.0383)$ & $(0.0383)$ & $(0.0383)$ & $(0.0421)$ \\
\hline \multirow[t]{2}{*}{ One-tiered_management } & $-0.0785^{* * *}$ & $-0.0790 * * *$ & $-0.0801 * * *$ & $-0.0813^{* * *}$ & $-0.0808 * * *$ & $-0.0557 * *$ \\
\hline & $(0.0256)$ & $(0.0257)$ & $(0.0256)$ & $(0.0260)$ & $(0.0256)$ & $(0.0267)$ \\
\hline \multirow[t]{2}{*}{ Minority } & $0.0560 *$ & $0.0557^{*}$ & $0.0576^{*}$ & $0.0573^{*}$ & $0.0562 *$ & $0.0567^{*}$ \\
\hline & $(0.0308)$ & $(0.0308)$ & $(0.0308)$ & $(0.0308)$ & $(0.0308)$ & $(0.0316)$ \\
\hline \multirow[t]{2}{*}{ Age } & $-0.00256 * * *$ & $-0.00253^{* * *}$ & $-0.00249 * * *$ & $-0.00248 * * *$ & $-0.00250 * * *$ & 0.000476 \\
\hline & $(0.000882)$ & $(0.000884)$ & $(0.000884)$ & $(0.000884)$ & $(0.000884)$ & $(0.000957)$ \\
\hline \multirow[t]{2}{*}{ Volatility } & $-8.74 e-06$ & $-8.89 e-06$ & $-1.59 e-05$ & $-1.29 \mathrm{e}-05$ & $-1.87 e-05$ & $-1.63 e-05$ \\
\hline & $(0.000229)$ & $(0.000229)$ & $(0.000229)$ & $(0.000229)$ & $(0.000229)$ & $(0.000232)$ \\
\hline
\end{tabular}


Table 15. Continued

\begin{tabular}{|c|c|c|c|c|c|c|}
\hline Variables & $\begin{array}{c}\text { (1) } \\
\text { Model } 1\end{array}$ & $\begin{array}{c}\text { (2) } \\
\text { Model } 2\end{array}$ & $\begin{array}{c}\text { (3) } \\
\text { Model } 3\end{array}$ & $\begin{array}{c}(4) \\
\text { Model } 4\end{array}$ & $\begin{array}{c}\text { (5) } \\
\text { Model } 5\end{array}$ & $\begin{array}{c}(6) \\
\text { Model } 6\end{array}$ \\
\hline \multirow[t]{2}{*}{ LogBoardsize*Leverage } & & & & & 0.0542 & \\
\hline & & & & & $(0.0373)$ & \\
\hline \multirow[t]{2}{*}{ Log Boardsize*Cash lag1 } & & & & & & 0.0579 \\
\hline & & & & & & $(0.0547)$ \\
\hline \multirow[t]{2}{*}{ Cash lag1 } & & & & & & 0.00567 \\
\hline & & & & & & $(0.0735)$ \\
\hline \multirow[t]{2}{*}{ Constant } & $0.149 * * *$ & $0.140 * * *$ & $0.0949 *$ & 0.0815 & $0.0974^{*}$ & 0.0505 \\
\hline & $(0.0255)$ & $(0.0482)$ & $(0.0542)$ & $(0.0724)$ & $(0.0542)$ & $(0.0593)$ \\
\hline Observations & 2,299 & 2,296 & 2,296 & 2,296 & 2,296 & 2,132 \\
\hline R-squared & 0.075 & 0.075 & 0.077 & 0.077 & 0.077 & 0.074 \\
\hline Number of IndexF-test & 2974.38 & 2974.36 & 2974.36 & 2974.36 & 2974.37 & 2954.30 \\
\hline
\end{tabular}

Standard errors in parentheses and corrected for clustering at firm level. ${ }^{* *},{ }^{* *},{ }^{*}$ indicate significance at the $1 \%, 5 \%$ and $10 \%$ level. Year fixed effects are not reported. 
Table 16. GMM-type dynamic panel regression models, dependent variable: ROA

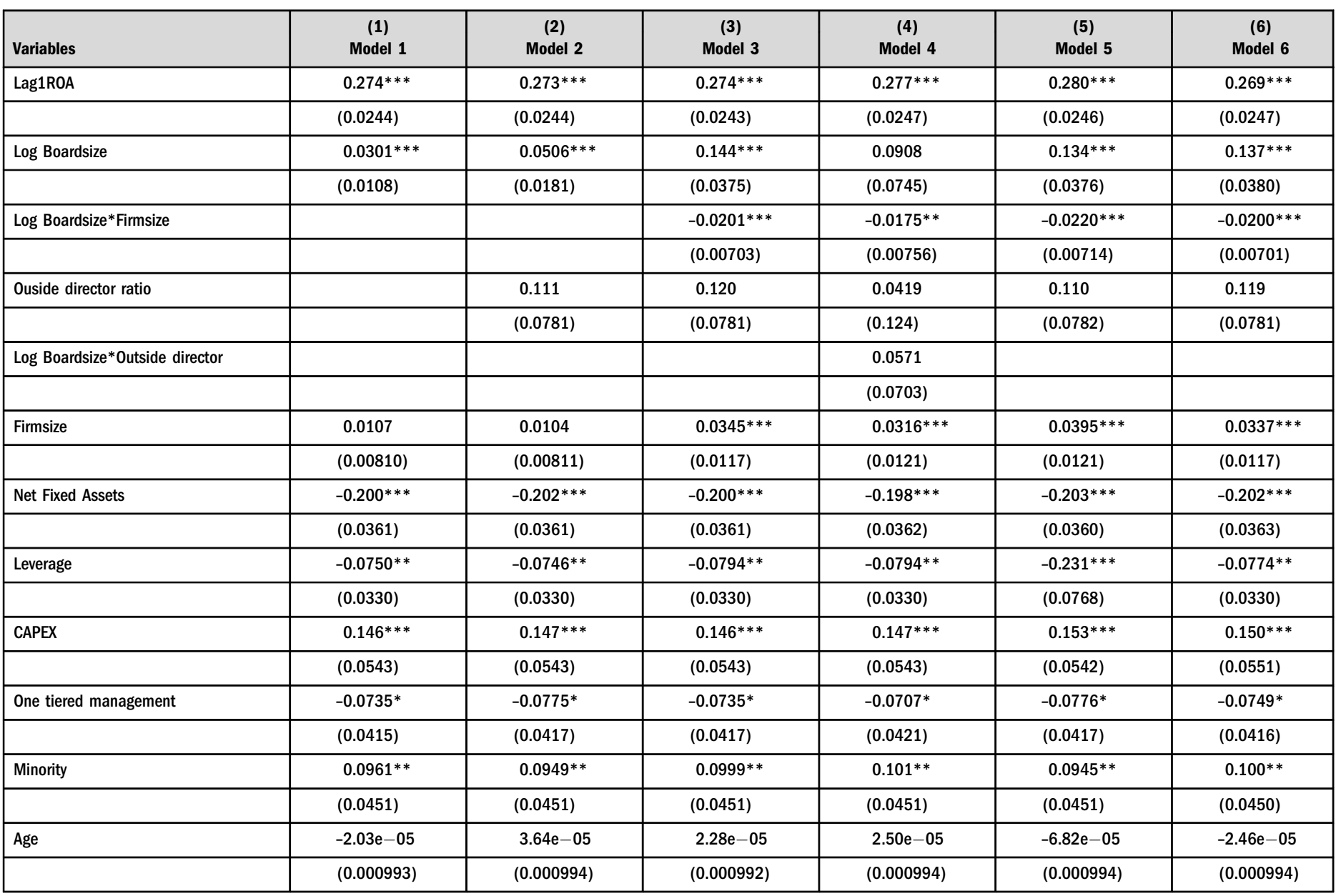


Table 16. Continued

\begin{tabular}{|c|c|c|c|c|c|c|}
\hline Variables & $\begin{array}{c}\text { (1) } \\
\text { Model } 1\end{array}$ & $\begin{array}{c}(2) \\
\text { Model } 2\end{array}$ & $\begin{array}{c}\text { (3) } \\
\text { Model } 3\end{array}$ & $\begin{array}{c}\text { (4) } \\
\text { Model } 4\end{array}$ & $\begin{array}{c}\text { (5) } \\
\text { Model } 5\end{array}$ & $\begin{array}{c}(6) \\
\text { Model } 6\end{array}$ \\
\hline \multirow[t]{2}{*}{ Volatility } & $9.53 \mathrm{e}-05$ & $8.78 \mathrm{e}-05$ & $8.36 \mathrm{e}-05$ & $8.82 \mathrm{e}-05$ & $9.32 \mathrm{e}-05$ & $8.07 e-05$ \\
\hline & $(0.000267)$ & $(0.000267)$ & $(0.000267)$ & $(0.000267)$ & $(0.000266)$ & $(0.000266)$ \\
\hline \multirow[t]{2}{*}{ Log Boardsize*Leverage } & & & & & $0.125^{* *}$ & \\
\hline & & & & & $(0.0569)$ & \\
\hline \multirow[t]{2}{*}{ Log Boardsize*Cash lag1 } & & & & & & 0.0851 \\
\hline & & & & & & $(0.0777)$ \\
\hline \multirow[t]{2}{*}{ Cash lag1 } & & & & & & -0.0912 \\
\hline & & & & & & $(0.103)$ \\
\hline \multirow[t]{2}{*}{ Constant } & 0.0191 & -0.0713 & $-0.184^{* *}$ & -0.114 & $-0.174^{* *}$ & $-0.171 * *$ \\
\hline & $(0.0356)$ & $(0.0727)$ & $(0.0833)$ & $(0.118)$ & $(0.0833)$ & $(0.0840)$ \\
\hline Observations & 2,130 & 2,128 & 2,128 & 2,128 & 2,128 & 2,128 \\
\hline
\end{tabular}

Standard errors in parentheses and corrected for clustering at firm level. ${ }^{* *},{ }^{* *},{ }^{*}$ indicate significance at the $1 \%, 5 \%$ and $10 \%$ level. Year fixed effects are not reported. 